\title{
Molecular and cellular mechanisms underlying the evolution of form and function in the amniote jaw
}

\author{
Katherine C. Woronowicz ${ }^{1,2}$ and Richard A. Schneider ${ }^{1 *}$ (D)
}

\begin{abstract}
The amniote jaw complex is a remarkable amalgamation of derivatives from distinct embryonic cell lineages. During development, the cells in these lineages experience concerted movements, migrations, and signaling interactions that take them from their initial origins to their final destinations and imbue their derivatives with aspects of form including their axial orientation, anatomical identity, size, and shape. Perturbations along the way can produce defects and disease, but also generate the variation necessary for jaw evolution and adaptation. We focus on molecular and cellular mechanisms that regulate form in the amniote jaw complex, and that enable structural and functional integration. Special emphasis is placed on the role of cranial neural crest mesenchyme (NCM) during the species-specific patterning of bone, cartilage, tendon, muscle, and other jaw tissues. We also address the effects of biomechanical forces during jaw development and discuss ways in which certain molecular and cellular responses add adaptive and evolutionary plasticity to jaw morphology. Overall, we highlight how variation in molecular and cellular programs can promote the phenomenal diversity and functional morphology achieved during amniote jaw evolution or lead to the range of jaw defects and disease that affect the human condition.
\end{abstract}

Keywords: Amniote jaw development and evolution, Form and function, Neural crest, Secondary cartilage, Mechanical environment

\section{Introduction}

The jaws of amniotes display a marvelous array of sizes and shapes, and there are countless examples of how the form of the jaws has evolved to function in every conceivable ecological niche [1-7]. One obvious purpose for the jaw apparatus is to obtain, manipulate, process, and ingest dietary items. For instance, among reptiles, many snakes often consume prey larger than their own skulls and can accommodate extreme expansion with highly flexible upper and lower jaws. Large prey is incrementally forced down the esophagus by "snout shifting" or "pterygoid walking" in which tooth-bearing elements of the upper jaw alternately ratchet over the prey [8].

\footnotetext{
*Correspondence: rich.schneider@ucsf.edu

${ }^{1}$ Department of Orthopaedic Surgery, University of California at San Francisco, 513 Parnassus Avenue, S-1161, Box 0514, San Francisco, CA 94143-0514, USA

Full list of author information is available at the end of the article
}

Additionally, while most amniote jaws are bilaterally symmetrical, snail-eating snakes (i.e., Pareas) have broken the symmetry of the dentition on their mandibles and develop more teeth on the right side as a means to prey upon clockwise-coiled (dextral) snails $[9,10]$. Similarly, among birds, crossbills (i.e., Loxia) have bilaterally and dorsoventrally asymmetrical beaks such that the distal tips traverse one another. The lower jaw crosses to the left or right side with equal frequencies in crossbill populations [11] and this unusual adaptive co-evolution permits these birds to pry open conifer cone scales and extract seeds [12,13]. Within mammals, giant anteaters (i.e., Myrmecophaga), which retrieve insects from tightly confined spaces like insect burrows, have evolved a specialized ability to "open" their jaws by rotating their mandibles along the long axis rather than by depressing the mandibles [14]. These are but a few extreme examples of what amniotes have accomplished with their jaws. 
Yet while myriad jaw morphologies exist today and in the fossil record, all amniote jaws share common developmental and evolutionary origins, and their form and function are typically achieved by integrating many of the same adjoining skeletal, muscular, nervous, vascular, and connective tissue components [15, 16]. How then does the species-specific form of the jaws emerge in development and change during evolution in relation to function? In particular, what molecular and cellular mechanisms pattern the jaws of embryos in a manner that anticipates later adult use and promotes adaptation? These are fundamental questions in biology and there is a long history of efforts to answer them using the jaw complex as a subject of study.

Early attempts to link form and function in the jaws as well as the skull more broadly began at the gross anatomical level. Meticulous descriptions conducted in a transcendental and pre-evolutionary framework such as those from Goethe, Oken, Dumeril, Geoffroy, Owen, and many others laid the foundation for comparative methods to study morphological variation and adaptation [17-19]. Describing form and function among animals required special language, and Owen coined, "homology" and "analogy" with this goal in mind. Such concepts facilitated discussions about the structural plan for vertebrates and whether cranial elements being compared across taxa were indeed "the same organ in different animals under every variety of form and function" [20, p. 379]. In line with the transcendentalists before him, Owen postulated that the vertebrate skull and its constituent parts like the jaws extended as a serial homolog of the trunk skeleton $[21,22]$. Owen's ideas impacted the way the concept of homology and the anatomy of the cranial complex were viewed and debated for years thereafter $[3,19$, 23-33]. During the nineteenth century, questions of form and function became rooted in comparative embryology, especially around the anatomical discoveries of workers like Rathke, Reichert, and Huxley, and the proposed laws of Haeckel [16, 18, 34, 35]. For example, Haeckel used his observations on the pharyngeal arches of various embryos to help explain how ontogeny could connect the forms of animals in a phylogenetic progression. Although Haeckel and his followers concluded rather erroneously that "ontogeny recapitulates phylogeny" [36], such early work built a vocabulary and an intellectual framework through which the mechanisms of structural and functional integration in the head could be probed for almost 200 years and up to the present.

Yet while the evolutionary history and comparative anatomy of the jaws have been well characterized, many questions remain as to how individual components arise during development and achieve their requisite form and function. Derivatives of all three germ layers (i.e., ectoderm, mesoderm, endoderm), but especially the cranial neural crest mesenchyme (NCM), which is a major contributor to the jaws, must communicate seamlessly to produce a musculoskeletal system that is structurally integrated in support of its normal and often highly specialized use. Achieving such species-specific form and function in the jaws is a dynamic multidimensional problem that embryos have to solve [37]. In particular, there need to be mechanisms in place facilitating the species-specific modulation of parameters such as cell cycle length, cell size, cell number, cell specification, cell fate, cell differentiation, and more [7, 38-43]. Teasing apart such mechanisms as well as those underlying the migration, distribution, and interactions among jaw precursor populations (Fig. 1a), and also identifying the critical signals through which these cells acquire and implement their axial orientation, anatomical identity, and tissue type, is essential for understanding how the jaws become patterned and structurally integrated. By applying modern experimental strategies, the molecular and cellular events that underlie jaw form and function during development, disease, and evolution are being elucidated. Some of these studies and their key insights are reviewed in the sections below.

\section{Anatomical organization and integration of the jaw apparatus}

The head skeleton has classically been organized into three compartments each with distinct embryological and evolutionary histories, anatomical locations, and various degrees of structural and functional integration: the neurocranium, viscerocranium, and dermatocranium (Fig. 1b) [3, 15, 19, 44-47]. The neurocranium has been defined as the skeleton that primarily forms first as cartilage and surrounds the brain and sense organs. The viscerocranium (or "splanchnocranium") has been viewed as the cartilaginous skeleton of the jaws and of the serially repeated arches in the pharyngeal region of the gut tube. The neurocranium and viscerocranium are thought to have evolved as part of a vertebrate endoskeleton [3, $22,48-50]$. In contrast, the dermatocranium has been described as a component of the vertebrate exoskeleton, which in the skull consists of the palatal, cranial vault, and tooth-bearing elements around the oral cavity [46, 51-54]. Moreover, these skeletal systems have divergent embryonic origins in terms of cell lineages and process of differentiation $[19,37,47,50,55,56]$.

In jawed vertebrates, the neurocranium and dermatocranium develop from dual mesenchymal lineages (i.e., mesodermal mesenchyme and NCM), whereas the viscerocranium forms predominantly from NCM $[54,57-70]$. Some aspects of the more posterior viscerocranial cartilages, such as in the laryngeal skeleton 

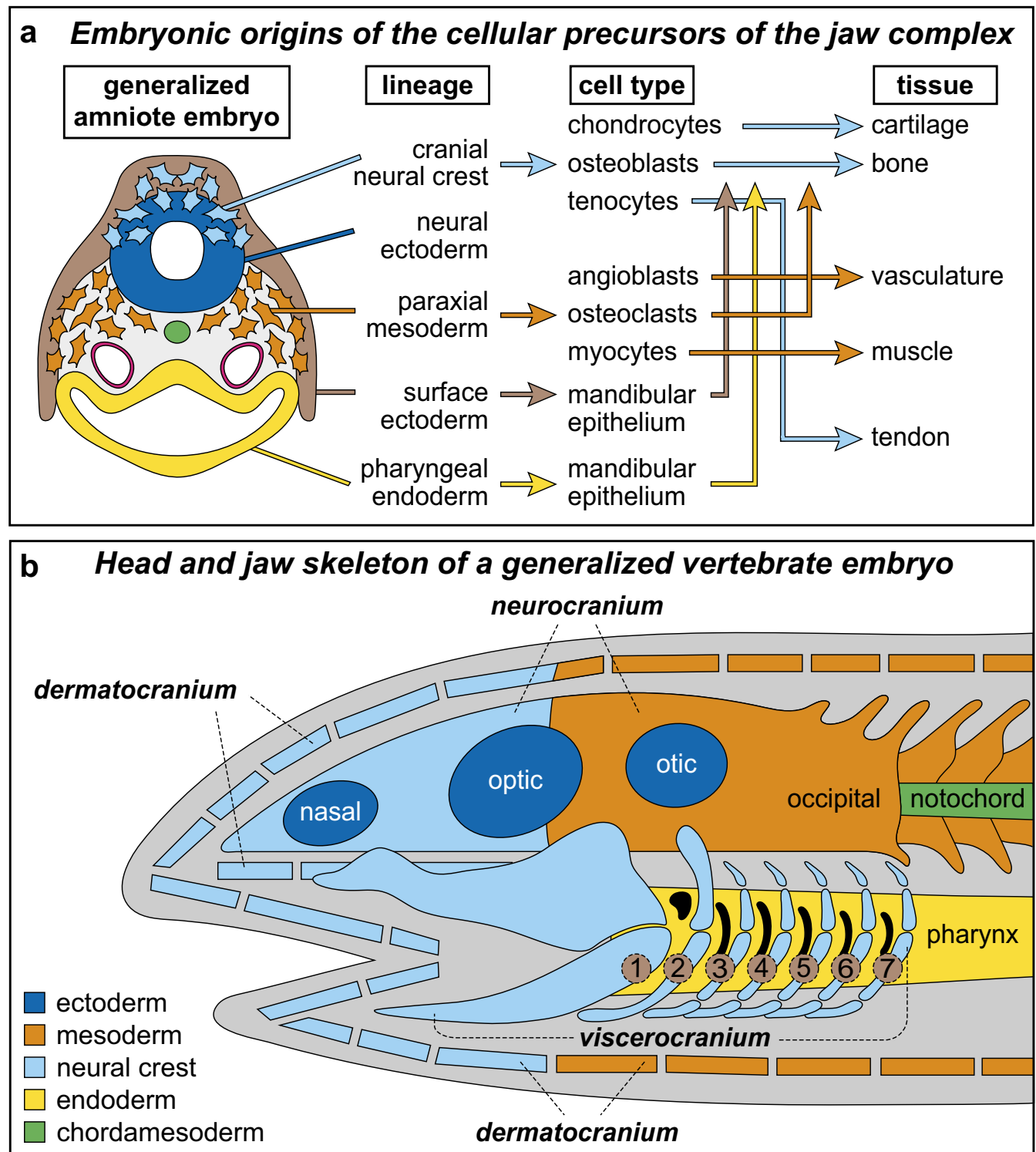

Fig. 1 The embryonic origins of the jaw are highly conserved across amniotes despite species-specific differences in form and function. a Schematic transverse section through the midbrain-hindbrain boundary of a generalized amniote after neurulation showing the major lineages of cells and their cell types, cell-cell interactions (vertical arrows), and tissue derivatives that contribute to the jaw apparatus. b Head and jaw skeleton of a generalized vertebrate embryo showing the spatial arrangements of the neurocranium, viscerocranium, and dermatocranium. The neurocranium forms first as cartilage and surrounds the brain and sense organs such as in the nasal, optic, and otic capsules. The viscerocranium is the cartilaginous skeleton of the jaws and of the serially repeated arches (numbers 1 to 7 ) along the pharynx. The first arch is the mandibular arch, which consists of the palatoquadrate cartilage above and Meckel's cartilage below. The second arch is the hyoid arch. The dermatocranium consists of the palatal, cranial vault, and tooth-bearing elements around the oral cavity. The viscerocranium is derived almost exclusively from NCM whereas the neurocranium and dermatocranium arise from both NCM and mesoderm (Modified and adapted from [22, 33, 38, 44, 75, 326, 395])

also appear to have contributions from mesoderm in amniotes [63, 71-73] and anamniotes [74, 75]. For the most part, the primary cartilages of the neurocranium and viscerocranium typically get replaced by bone through endochondral and perichondral ossification. Such bones are termed "cartilage bones" [3,
$35,51]$. In contrast, most skeletal elements associated with the dermatocranium are not pre-formed in cartilage but arise principally as condensations of NCM and/or mesodermal mesenchyme that differentiate directly into "dermal bone" through intramembranous ossification [15, 19, 46, 51, 54, 62, 76-80]. However, 
these definitions are not exclusive as there are some endoskeletal bones that ossify intramembranously (e.g., "membrane bones") and some exoskeletal bones that develop in conjunction with cartilage (e.g., "secondary" or "adventitious cartilage" of birds and mammals) [50, $51,80]$.

During intramembranous ossification, mesenchymal cells condense and secrete a dense extracellular matrix, called osteoid, which is rich in collagen I and other fibers [81, 82]. Shortly afterward, osteoid mineralizes by incorporating calcium phosphate crystals that are absorbed from the vasculature and which provide rigidity to the fibrous network. During cartilage formation, mesenchymal cells condense and secrete an extracellular matrix rich in collagen II and other fibers to produce an avascular tissue [51, 80, 83, 84]. This process causes a tissue expansion such that chondrocytes become separated by vast amounts of extracellular matrix. Typically, as chondrocytes mature, they undergo apoptosis, vasculature invades the cartilage and brings in mineral, and the cartilage template is replaced by bone through endochondral ossification [79, 80, 85]. Despite these differences in how they differentiate, elements that transform from cartilage to bone via endochondral and perichondral ossification, and bones that arise directly through intramembranous ossification, become seamlessly integrated both structurally and functionally among the neurocranium, viscerocranium, and dermatocranium.

The amniote jaw skeleton contains elements from the viscerocranium and dermatocranium. The viscerocranial elements are derived from the pharyngeal arches, which are transient embryonic structures that produce upper and lower skeletal portions, as well as associated muscular, nervous, and circulatory elements [15, 19, 86, 87]. The jaws proper arise within the first pharyngeal arch, which is the mandibular arch. There has been considerable debate as to the boundaries between the mandibular arch and the region more anterior (i.e., "premandibular"), and also the extent to which the mandibular arch is in fact serially homologous with the other pharyngeal arches based on differences in the embryology and early patterning events of the oral cavity versus the pharynx [88-94]. Thus, some have suggested using terms like "oropharyngeal" to reflect these differences $[19,95]$.

In an influential but rather speculative hypothesis, the evolutionary origin and diversification of the vertebrate jaws were claimed to be tied to the emergence and elaboration of NCM, and a shift from passive, sessile feeding to active modes of predation [96-98]. While clearly the NCM (along with epidermal thickenings called placodes) have been essential to the success of vertebrates, vertebrates were likely active feeders long before they evolved jaws [99]. Nonetheless, after the jaws emerged in basal vertebrates, many of the same anatomical units and constituent parts have remained conserved across the various lineages including amniotes, albeit with some modifications and exceptions [3, 15]. In a generalized common ancestor for amniotes, the upper skeletal portion of the jaw (i.e., viscerocranial) contained the palatoquadrate cartilage while the lower portion consisted of Meckel's cartilage (Fig. 2a). During the evolution of modern amniotes (Fig. 2b), however, these two cartilages no longer become the main contributors to the functional adult jaws. In reptiles and birds, the palatoquadrate is divided into two distinct cartilages, the epipterygoid and the quadrate (Fig. 2c) [100]. Generally, the epipterygoid contributes to the side of the braincase while the quadrate suspends the jaw skeleton from the temporal region of the skull [101-103]. In place of the palatoquadrate, the functional upper jaw of amniotes is made up of dermal bones from the dermatocranium, including the premaxilla, maxilla, quadratojugal, palatine, and pterygoid (Fig. 2d) [3, 45, 104].

In the lower jaw, Meckel's cartilage typically persists as a cylindrical rod that rarely goes on to ossify [3, 105107]. The lower jaw of reptiles and birds is also made up of several separate dermal bones from the dermatocranium that surround Meckel's cartilage including the dentary, surangular, angular, and splenial (Fig. 2d) [100, 108-110]. Distinct from these dermal bones, the articular cartilage ossifies within the proximal portion of Meckel's cartilage and contacts the quadrate cartilage to form the jaw joint. Thus, the actual connection between the upper and lower jaws of reptiles and birds comes from two ossified remnants (i.e., quadrate and articular) of the ancestral viscerocranial upper and lower portions of the first oropharyngeal arch [102]. This also typifies the jaw joint for all non-mammalian jawed vertebrates.

In contrast, the mammalian jaw skeleton is highly derived from the ancestral amniote condition. First, the homolog of the epipterygoid helped close off the expanded mammalian braincase by giving rise to a portion of the mammalian alisphenoid bone (Fig. 2e) [111-114]. Second, the functional lower jaw went from having up to six different bones to a single bone, the dentary (i.e., mandible) (Fig. 2f) [45, 115]. Third, the quadrate became reduced in size, no longer participated in the jaw joint, and evolved into the incus, which is one of the mammalian middle ear ossicles [116-118]. During this evolutionary transformation, the articular, like the quadrate, became modified into another middle ear ossicle, the malleus [117]. In association with the viscerocranial jaw joint becoming middle ear ossicles, a new jaw joint formed in the dermatocranium between the dentary and squamosal bones (i.e., the dentarysquamosal or temporal-mandibular joint) of mammals 

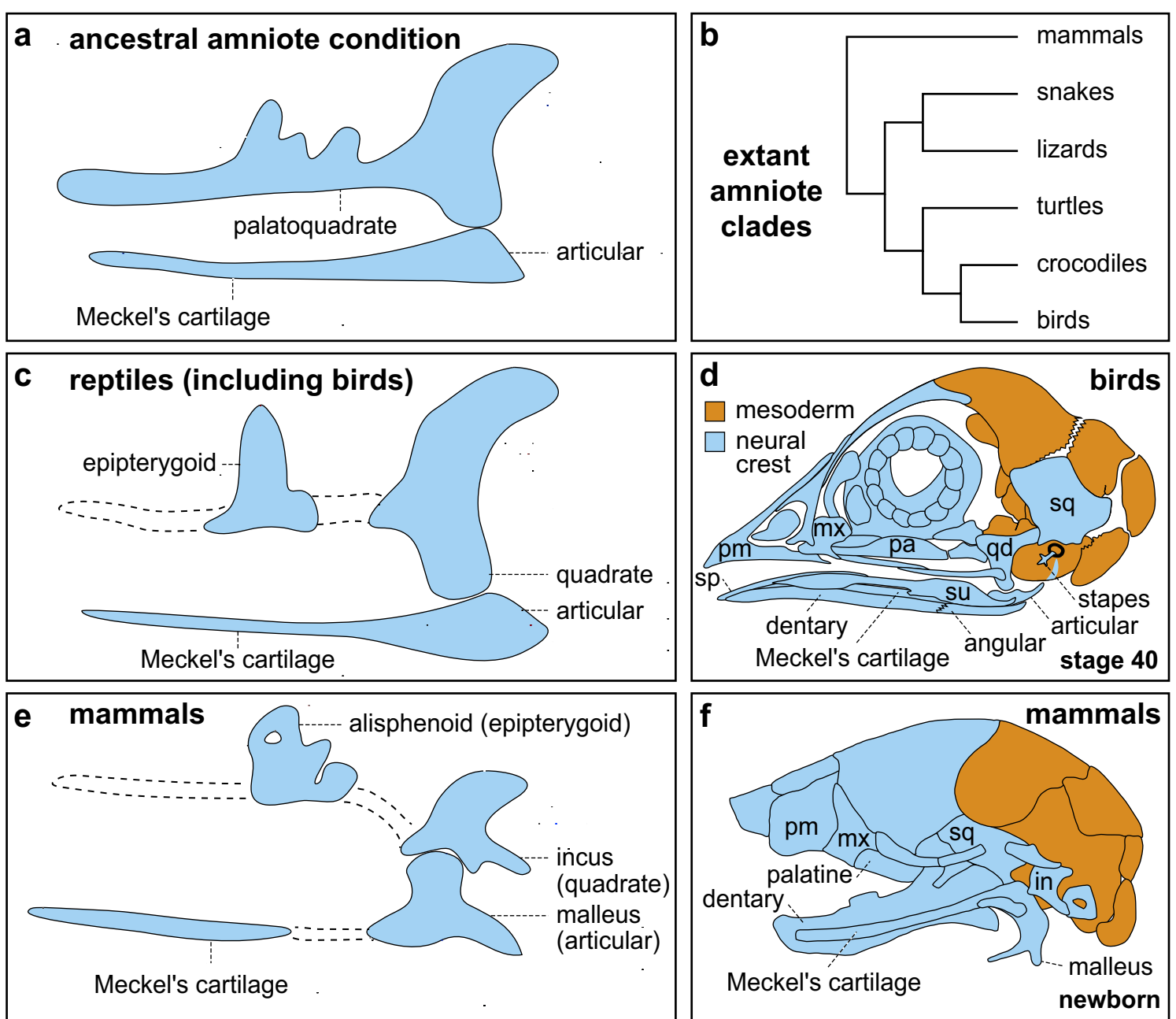

Fig. 2 The amniote jaw skeleton has undergone evolutionary diversification in form and function. a Development of upper and lower cartilaginous elements of the mandibular arch in a generalized ancestral amniote. The cartilaginous upper jaw of an ancestral amniote consists of the palatoquadrate cartilage, which is a single element. The lower jaw contains Meckel's cartilage with the articular cartilage at the most proximal end. $\mathbf{b}$ During the radiation of amniotes into the major clades of reptiles (including snakes, lizards, turtles, crocodiles, and birds) and mammals, the ancestral amniote condition became modified. $\mathbf{c}$ In reptiles and birds, all that persists of the palatoquadrate is the epipterygoid and quadrate cartilages that develop along condensations of NCM (dashed lines). The quadrate is the upper portion of the jaw joint and the articular cartilage is the lower portion. $\mathbf{d}$ In place of the palatoquadrate, the functional upper jaw of reptiles and birds is composed of dermal bones including the premaxilla (pm), maxilla (mx), and palatine (pa). The lower jaw is also made up of several dermal bones that surround Meckel's cartilage including the dentary, surangular (su), angular, and splenial (sp). The amniote jaw skeleton is derived entirely from neural crest mesenchyme (NCM; light blue) whereas some elements in the skull roof are derived from mesoderm (orange). e In mammals, the epipterygoid contributes to part of the alisphenoid bone and the quadrate becomes the incus (in), which is an ossicle in the middle ear. In mammals, the articular cartilage becomes the malleus (ma) in the middle ear. $\mathbf{f}$ Mammals evolve an entirely new jaw joint between the dentary and squamosal (sq) bones, as the incus (in) and malleus (ma) become incorporated into the middle ear. The lower jaw is reduced to a single bone, the dentary (i.e., mandible) (Modified and adapted from $[19,37,73,102,138,140,396])$

$[119,120]$. Such a transformation demonstrates how jaw bones can be repurposed to have new functions [121-123]. In this case, bones that once supported feeding become bones for hearing [117, 118, 120, 124]. So, while in reptiles and birds, the bones that conduct sound to the inner ear remain closely associated with the jaw, in mammals, the sound-conducting middle ear ossicles become isolated from the jaw joint and encapsulated within the skull [125]. Such an arrangement apparently confers mammals with an efficient auditory system capable of detecting high frequencies and protected from the masticatory apparatus [126]. 
In general, jaw movement is enabled by pairs of adductor, abductor, and levator muscles that insert onto various aspects of the mandible [127-129]. The main jaw adductor muscles are innervated by the trigeminal nerve (n. V) whereas the abductors are innervated by the facial nerve (n. VII) [130]. For most amniotes, lateral movement is fairly restricted and jaw adduction and abduction occurs at the parasagittal plane. The mammalian jaw adductor complex underwent significant rearrangement and modification in association with the evolution of mastication and presumably the need to increase bite force $[123,131]$. Mammals also evolved a novel series of pharyngeal elevators and constrictors to support their unique swallowing and suckling behaviors $[95,132]$.

As in the rest of the musculoskeletal system, the muscles and bones of the jaw are joined by tendons, which are continuations of the connective tissue fascia that ensheath skeletal muscles. In contrast to muscle and bone, which are well vascularized, tendons are avascular. Tendons primarily distribute tensile forces from muscle to bone and the junction between tendon and bone, called an enthesis, is marked by a transition zone between the fibrous matrix of tendon and the mineralized matrix of bone [133-135]. Bundles of densely packed and axially aligned fibers (i.e., Sharpey's) that comprise tendons must smoothly transform into cortical bone for effective transmission of mechanical loads. Moreover, fibrocartilage may develop within compressed regions when tendon is wrapped against the surface of bone, which can help create a gradient in material properties along the transition from soft to hard tissues (i.e., tendon to bone) and dissipate the stress concentration at the bony interface [136]. The hallmarks of fibrocartilaginous tendons include sparsely distributed chondrocytes and a cartilaginous matrix enriched with molecules associated with resisting compression [137].

In order for each of the cartilages, bones, muscles, and tendons of the amniote jaw complex to attain proper form, achieve structural integration, and become functionally enabled, their precursor populations must acquire and/or act upon multiple dimensions of patterning. These dimensions include developing with the appropriate cell and tissue type (e.g., chondrocyte, osteoblast, myocyte, tenocyte), axial orientation (e.g., dorsalventral, rostral-caudal, proximal-distal, medial-lateral), anatomical identity (e.g., upper jaw versus lower jaw), and species-specific size and shape (e.g., mouse-like versus human-like, or quail-like versus duck-like) [37, 42, 138]. Clearly, each component within the jaw complex can be transformed rapidly and dramatically during the course of amniote evolution (and also in the case of birth defects), and undoubtedly this occurs via changes in the molecular and cellular programs that underlie the multiple dimensions of patterning. However, such changes must be constrained on one level or another because over the long run, the essential internal relationships among the various musculoskeletal elements have to be maintained with high fidelity and in a manner that meets any necessary functional demands. How this happens could be considered an emergent property of all the signaling pathways and gene regulatory networks that are deployed over time across three-dimensional space, as well as the embryonic histories and iterative interactions of every contributing cell and tissue. In this regard, the developmental biology of the jaw apparatus seems almost infinitely complicated to sort out. Nonetheless, good progress can be made in characterizing the multidimensional and dynamic system that generates the amniote jaw complex by focusing on the hierarchical levels of anatomic and embryonic organization, by identifying common principles, and by emphasizing fundamental molecular and cellular mechanisms.

\section{Cellular origins of musculoskeletal tissues in the jaw}

The cartilages and bones in the upper and lower portions of the amniote jaws arise within embryonic prominences flanking the stomodeum, or presumptive oral cavity (Fig. 3a). The first oropharyngeal arch (i.e., mandibular arch) contains two pairs of prominences: the maxillary processes, which lie lateral to the stomodeum and give rise to the secondary palate and portions of the upper jaws; and the mandibular processes, which lie inferior to the stomodeum and produce the lower jaws $[139,140]$. Additional prominences, specifically the frontonasal process in reptiles and birds, and the lateral and medial nasal processes in mammals, give rise to the mid and upper face and the primary palate [141-144]. Modulating growth and other parameters in these prominences enables diverse and complex morphologies to develop and evolve, but abnormal variation often causes facial and palatal clefting, which are some of the most common human birth defects [144-152].

The oropharyngeal arches are populated by NCM (Fig. 3b, c), which arises at the boundary between the neural plate and the non-neural ectoderm following an epithelial to mesenchymal transition [153-159]. NCM migrates extensively and produces numerous cell types in the jaw apparatus including all the chondrocytes that make cartilage, osteoblasts that make bone, tenocytes that make tendon, and ligamentous fibroblasts that make other muscle connective tissues (Fig. 1a) [19, 54, 62, 66-69, 77, 160-164]. NCM appears to be drawn from the neural tube to the oropharyngeal arches via chemoattractant gradients. Many molecules like fibroblast growth factors (FGF), vascular endothelial growth factors 

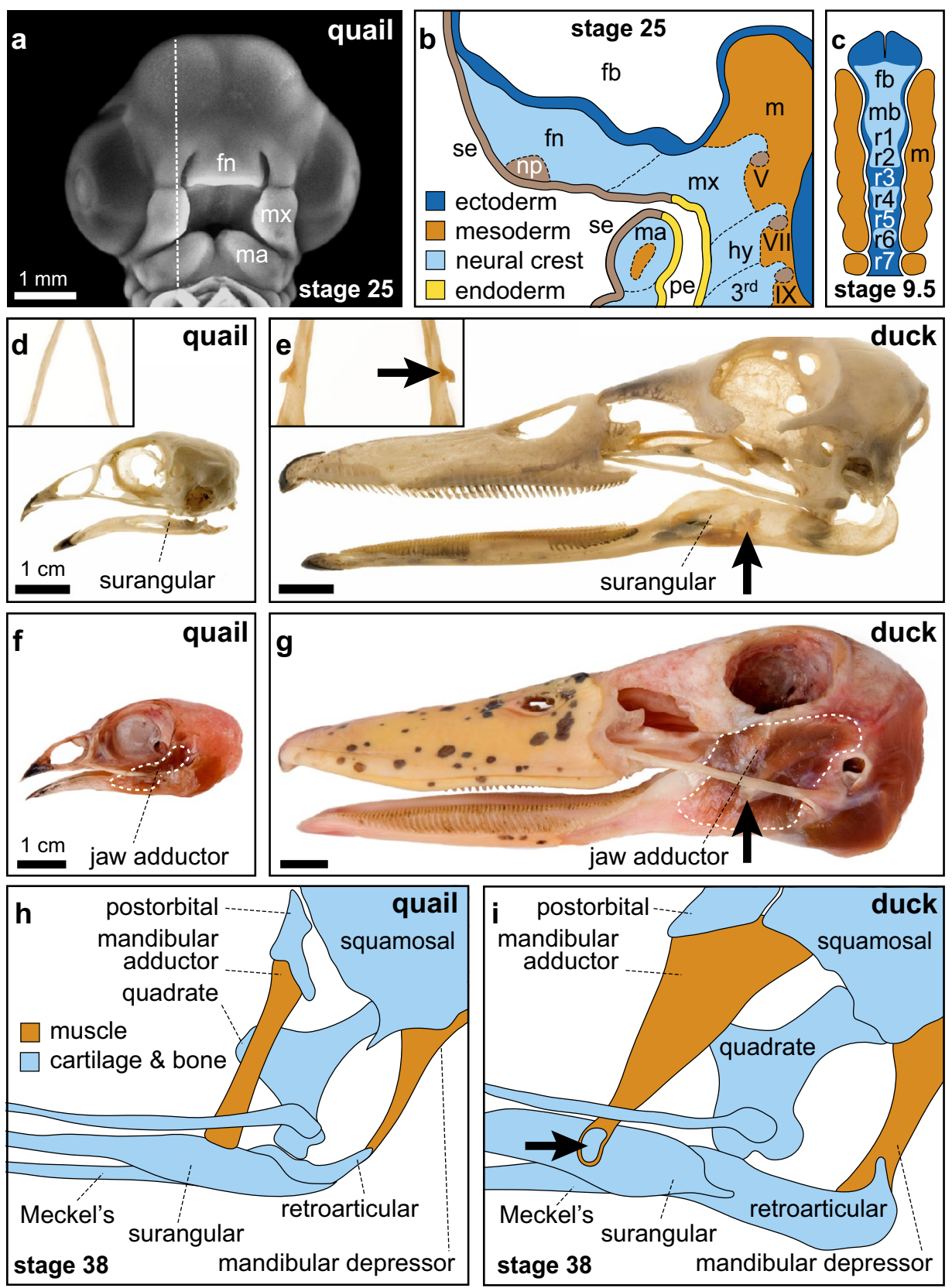

Fig. 3 The development of the amniote jaw complex involves critical contributions from multiple embryonic populations. a Frontal view of stage 25 quail embryo. The frontonasal (fn), maxillary ( $\mathrm{mx}$ ), and mandibular ( $\mathrm{ma}$ ) primordial are visible (dotted line indicates the sagittal section plane for b). b By stage 25, the frontonasal (fn), maxillary (mx), mandibular (ma), and hyoid (hy) primordia (sagittal view) are populated by NCM (light blue) surrounded by surface ectoderm (se; tan), pharyngeal endoderm (pe; yellow), and forebrain neuroepithelium (fb; dark blue) and contain contributions from neural crest, nasal placode (np), and cranial ganglia (V, VII, IX). Mesoderm (m) that produces skeletal tissues is distributed caudally. c Prior to migration, at stage 9.5 (dorsal view) cranial NCM (light blue) delaminates from the forebrain (fb), midbrain (mb), and hindbrain rhombomeres ( $r$; dark blue). Cranial NCM migrates alongside paraxial mesoderm ( $m$; orange). $\mathbf{d}$, e Head skeleton of adult quail and duck. The duck surangular bone, which lies dorsal to the dentary bone along the lower jaw (inset), contains a robust coronoid process (black arrow) along its lateral margin that is absent in quail. $\mathbf{f}, \mathbf{g}$ The mandibular adductor muscles (white dashed outline), which close the jaw, are relatively larger in ducks than in quails. The caudal external mandibular adductor muscle originates posterior to the orbit and inserts laterally on the duck coronoid process (black arrow). This muscle is relatively smaller in quails and inserts along the dorsal margin of the surangular. $\mathbf{h}$ By stage 38 in quails, the narrow mandibular adductor muscle (orange) inserts dorsally onto the coronoid process of the surangular bone (light blue). i By stage 38 in ducks, the broad mandibular adductor inserts laterally onto the coronoid process and contains a secondary cartilage (arrow) within the tendon enthesis (Modified and adapted from [6, 19, 37, 138, 140, 233, 283]) 
(VEGF), and other cytokines and secreted proteins are thought to attract migrating NCM, but whether such gradients are sufficient to guide long-range NCM migration remains an open question [165-169]. Other in vivo and in silico data predict that a chemoattractive gradient may not be required for collective NCM migration. Instead, contact inhibition may drive the long-range, directional migration of NCM [153, 169-172]. Repulsive signals also steer streams of migrating NCM by way of Eph/ephrin and neuropilin/semaphorin signaling for example [173175]. Likely a combination of contact inhibition along with attractive and repulsive signals regulates cranial NCM streaming and funnel NCM into their proper oropharyngeal destinations where they eventually differentiate as an array of interconnected jaw tissues.

Although NCM differentiates into many cell and tissue types, the extent of their initial developmental potency has been disputed. Conflicting interpretations of clonal analyses and lineage tracing experiments have obscured whether NCM is truly multipotent, or whether NCM is a diverse population of fate-restricted cells [162, 176-182]. For instance, studies using fluorescent "confetti" reporter mice reveal that individual migratory neural crest cells commonly contribute to many cell types and multiple tissues and suggest that NCM is indeed multipotent [183]. Correspondingly, the gene regulatory networks that direct NCM toward differentiation have become much better understood [184-188] and undoubtedly their continued delineation will help clarify the multifaceted genetic underpinnings of neurocristopathies, which often have widespread and debilitating effects [189-191].

Besides NCM, the development of the jaw complex also involves critical contributions from non-neural ectoderm and pharyngeal endoderm, which form the epithelia that surround the mandibular arch, as well as from paraxial mesoderm (Fig. 3b, c). Epithelial tissues derived from the non-neural ectoderm include placodes that produce tissues like olfactory epithelium in the nasal capsule as well as cranial ganglia like the trigeminal that support the innervation of the mandibular arch [194-199]. The epidermis, which becomes stratified into multiple layers, likewise comes from the nonneural ectoderm and produces the enamel of teeth [46, 76] as well as the keratinized portions of jaw structures such as horns, beaks, and egg teeth [193, 200-204]. Paraxial mesoderm gives rise to angioblasts that build blood vessels, osteoclasts that resorb bone, and myocytes that make skeletal muscle in the jaws $[63,71,128$, 161, 205-211].

Cranial skeletal muscles are distinct from trunk muscles in terms of the organization of their embryonic precursor populations and the gene regulatory networks that govern their differentiation [128, 205, 213-221]. Amniote jaw muscles derive from unsegmented populations of paraxial mesoderm [128, 161, 71, 206, 209] whereas in the trunk, skeletal muscles arise from paraxial mesoderm that is organized into segmented somites [222-225]. These differences not only reflect the complex developmental and evolutionary histories of the head but also seem to influence the patterns of muscle gene expression. While transcription factors like $M r f 4, M y f 5, M y o D$, and Myogenin are required for myogenesis throughout the body, the specific subsets of genes and the genetic hierarchy regulating these factors vary between cranial muscle groups [205]. For example, jaw muscles employ a suite of genes that is distinct from trunk muscles and even other cranial muscles $[217,218,226]$. Some signals like those from the bone morphogenetic protein (BMP) pathway repress muscle differentiation in both the head and trunk, while Sonic Hedgehog $(\mathrm{SHH})$ and Wingless (WNT) signaling promotes muscle differentiation in the trunk but inhibits muscle differentiation in the head [216]. Specifically, connective tissues surrounding head muscles express antagonists like Gremlin and Frizzledrelated protein (Frzb), which relieve repression of muscle development by BMPs and WNTs, respectively, and allow cranial muscles to differentiate.

The above example involving BMP and WNT signaling illustrates one of the many ways the patterning and differentiation of cranial skeletal muscle rely upon signals emanating from adjacent NCM-derived connective tissues. Myogenic precursors migrate alongside NCM en route to the first and second oropharyngeal arches [55, $161,71,227,228$ ] and multiple aspects of jaw muscle pattern are regulated by NCM-derived connective tissues such as fiber type, muscle orientation, and the precise locations of attachments [128, 205, 212, 218, 226, 229, 230]. This intimate spatial and temporal relationship is similar to what occurs in the trunk [225] where connective tissue fibroblasts (although these instead arise from trunk mesoderm) supply critical signals for both fast- and slow-twitch muscle differentiation and lay down the basic muscle patterns prior to tendon differentiation [231, 232].

Not only do such developmental interactions between $\mathrm{NCM}$ and mesodermal mesenchyme ensure the structural integration necessary for achieving appropriate muscle function during ontogeny, but they also seemingly help maintain the co-evolution of the musculoskeletal system throughout phylogeny. This conclusion is buttressed by results from chimeric transplant experiments that exploit the different jaw morphologies of quails and ducks (Fig. 3d-g). In particular, quail-duck chimeras have revealed the ability of NCM-derived tendon and muscle connective tissues to dictate the speciesspecific attachments of jaw muscles that have evolved 
in connection with the distinct modes of feeding that characterize each of these birds [6, 233]. For example, transplanting pre-migratory $\mathrm{NCM}$ from quail to duck embryos produces duck-host-derived muscles with quaillike shape and attachment sites [6]. Such mechanistic reliance of the jaw muscles on their associated connective tissues during development likely underlies the capacity of species to adapt by co-evolving their musculoskeletal system in ways that often seem astonishingly well suited for novel functions.

\section{Epithelial interactions underlying jaw patterning and differentiation}

Despite the wide variety of highly specialized jaw morphologies, the basic Bauplan and the underlying genetic modules of the developing jaw complex remain relatively conserved across amniotes. All amniote jaws are oriented such that the most proximal components articulate at a hinge even though the distal components may vary greatly in length and in form. To establish the correct positional information along the axes of the developing jaw skeleton, the mandibular arch relies upon discrete and nested molecular programs that are regulated by and affect the NCM. One elegant hypothesis to explain this phenomenon is known as the "hinge and caps model" wherein two appositional units (i.e., upper jaw and lower jaw) are thought to maintain their own intrinsic polarity through a patterning system that reflects the competence of NCM to respond to an array of positionally located epithelial signals [234]. In this context, species-specific changes to protein coding sequences, ligand and receptor expression domains, duration of gene expression, and/or sensitivity to signaling could allow the proportions and relative positions of skeletal elements to change along the proximodistal axis during evolution while simultaneously maintaining the basic "hinge and caps" organization of the jaws [38, 39, 235-239].

Numerous studies have shown that the signals from the epithelium are spatially and temporally dynamic and, in response, NCM expresses a combinatorial suite of transcription factors such as the Msx, Dlx, Prx, Hand, Six, Bapx, and Barx families, which in turn affects the anatomical identity of the maxillary and mandibular prominences [173, 240-260]. For example, perturbing $D l x$ gene expression transforms maxillary into mandibular jaw bones $[243,244,249]$. Such homeotic transformations caused by disruptions to homeobox genes like $D l x$ and others demonstrate that in general the stereotypic and programmatic responses of transcription factors, which are elicited by signals from adjacent epithelia, are a keystone of jaw morphogenesis. This is not unlike what happens along the anteroposterior axis of the trunk or the proximodistal axes of the limbs, which are patterned by overlapping expression domains of Hox-family transcription factors. However, a seemingly important difference is that the frontonasal process as well as the maxillary and mandibular primordia of the first oropharyngeal arch (unlike the more posterior arches such as the hyoid arch) are Hox free and, thus, they are reliant on different gene regulatory networks and signaling interactions to guide their morphogenesis [261-264].

One of the primary functions of these epithelial-mesenchymal signaling interactions is to establish axial polarity in the face and jaws. For example, to set up the dorsoventral axis of the upper jaw, retinoic acid (RA) signaling triggers a sequence of reciprocal signaling events among the neuroepithelium, NCM, and surface ectoderm [265-267]. Epithelial-mesenchymal signaling between the NCM and the surface ectoderm defines a signaling center called the frontonasal ectodermal zone (FEZ) that consists of complementary Fgf8 and Shh domains separated by a precise boundary [143, 268]. RA signaling maintains $F g f 8$ and Shh expression domains in both the neuroepithelium and surface ectoderm [265, 269]. Rotating the FEZ $180^{\circ}$ induces ectopic $F g f 8$ and Shh domains, extra dorsoventral axes, and supernumerary structures of the upper jaws such as duplicated cartilages and egg teeth in birds [141, 268].

Likewise, the anteroposterior axis of the jaw skeleton is established through interactions between NCM and the pharyngeal endoderm, which also relies on Shh expression to establish polarity and support cartilage development [79, 270-273]. Ablating localized regions or altering the growth of pharyngeal endoderm prevents formation of the quadrate, Meckel's cartilage, the articular, and the hyoid [274-276]. Rotating pharyngeal endoderm by $90^{\circ}, 180^{\circ}$, or $270^{\circ}$ leads to ectopic and correspondingly re-oriented cartilaginous elements. Finally, in terms of the mediolateral axis, ectopic midline structures like egg teeth can be induced in the lateral nasal process by simultaneous local inhibition of BMP signaling and the administration of exogenous RA, which presumably mimics the local signaling environment of the frontonasal process $[245,266]$. These experiments and many others underscore the critical role of epithelia and their cadre of secreted factors in establishing the axes of the jaw skeleton and ultimately the relative positions of individual jaw bones and cartilages [147, 148, 237, 265, 277-279].

As part of its genetic response to the epithelial interactions that establish the major axes and anatomical identity of skeletal elements along the jaws, NCM executes intrinsic developmental programs that impart individual cartilages and bones with species-specific size and shape. Such insight comes mostly from interspecific transplant experiments involving the embryos of salamanders, 
frogs, birds, and mice, which have shown that this aspect of patterning in the jaws is largely driven autonomously by the NCM [37, 39, 40, 42, 156, 280-286]. Chimeric model systems have also enabled mechanisms underlying the complex interactions between NCM and surrounding epithelial tissues to be interrogated on the molecular level. For instance, transplanting quail NCM into a duck host produces a smaller jaw with quail-like, speciesspecific morphology [7, 283, 287]. Such a complex morphological transformation is driven by NCM-mediated temporal and spatial changes in the expression of genes known to be involved in the patterning, differentiation, and growth of the jaw skeleton such as members and targets of the BMP, FGF, SHH, and transforming growth factor beta (TGF $\beta$ ) pathways [38, 40, 283, 287, 288]. Furthermore, NCM seems to be remarkably pliant and, for example, can even follow cues from the local developmental environment that normally pattern mesodermderived skeletal elements [114]. These experimental findings serve as a testament to the regulatory abilities, developmental plasticity, and evolutionary significance of the NCM during jaw evolution [7, 19, 37, 39, 96, 138, 140, 164, 191, 289].

Moreover, the use of an anatomically diverse range of model systems (especially avian) has enabled the developmental programs responsible for evolutionary changes to the dimensions of the jaw skeleton to be elucidated [290]. For example, studies involving Darwin's finches and other birds including chicks, ducks, quails, and cockatiels have not only uncovered components of genetic modules and/or gene regulatory networks that specify the axes of the jaw skeleton but have also helped elucidate how changes to these components can generate species-specific variation in depth, width, and length during evolution. In particular, BMP signaling affects depth and width whereas calcium signaling affects length [291-295]. Species-specific jaw length also appears to be dependent on NCM-mediated expression of enzymes involved in bone resorption such as matrix metalloproteinase 13 (Mmp13). In this case, quail embryos express high levels of MMP13 in the NCM-derived jaw skeleton while duck embryos express relatively little, and inhibiting MMP13 in quail embryos lengthens the jaw [38]. TGF $\beta$ and WNT signaling also appears to regulate the size and shape of the upper jaw [236]. Similarly, sequence changes in transcription factors like $A l x 1$ also affect species-specific jaw shape [296]. Finally, thousands of putative active enhancers seem to be operating during craniofacial morphogenesis indicating that there are many yet to be discovered mechanisms from paracrine signaling to transcriptional regulation likely governing the evolutionary diversification of jaw size and shape [297, 298].
Not only does the initial patterning of NCM in terms of axial orientation and anatomical identity require numerous reciprocal signaling interactions with adjacent epithelia but also the differentiation of NCM into skeletal tissues such as bone depends on these interactions as well [138, 288, 299]. For example, intramembranous ossification of the lower jaw requires precisely timed, reciprocal interactions with overlying epithelium. Surgically removing mandibular epithelium prevents NCM from forming bone $[288,299]$. However, there does not seem to be anything intrinsically osteogenic about mandibular epithelium since NCM can still make bone in the mandibular primordia even when interacting with epithelium from the forelimb [300]. These and other tissue recombination experiments reveal that NCM helps establish the location of osteogenesis during jaw development likely through some yet to be identified instructive signals.

NCM also controls the timing of mandibular osteogenesis. If mandibular epithelium is removed at an early stage, then jaw bone fails to form. However, at a slightly later stage (presumably after some critical signaling events between NCM and the mandibular epithelium have occurred) bone can form in the absence of the epithelium $[288,299]$. While on the surface this would suggest that the epithelium determines when bone forms, quail-duck chimeras demonstrate that the precise timing of this epithelial-mesenchymal interaction and ultimately the induction of bone is reliant upon an NCM-mediated developmental program involving BMP signaling [288]. Quail embryos develop faster than duck embryos due to intrinsic differences in their rates of maturation (17 versus 28 days from fertilization to hatching). When NCM is transplanted unilaterally from quails to ducks, the entire program for osteogenesis is accelerated and precocial bone forms on the quail-donor side three developmental stages earlier than on the contralateral duck-host side [40]. Additionally, in chimeras, bone can form much sooner in the absence of epithelium coincident with the presence of faster-developing quail donor NCM [288]. NCM appears to accomplish this task by using BMP signaling to govern the timing of interactions with epithelium as well as jaw bone formation. The ability of NCM to exert control over the location and timing of key osteogenic events as well as the regulation of critical signaling pathways provides another crucial insight into how NCM acts as a fundamental developmental mechanism linking the species-specific evolution of form with function in the amniote jaw skeleton. 


\section{The role of mechanical forces in jaw form and function}

During embryogenesis, the formation and growth of jaw tissues are also influenced by external factors, including the mechanical environment. Throughout the body, muscles, bones, and tendons respond and adapt to mechanical stimulation via various mechanotransduction pathways, often undergoing hypertrophy in the presence of increased loading, and atrophy with disuse [136, 137, 301-305]. In sites where tendons transduce high magnitude forces from muscles, bony eminences may form. Pools of cells which express both cartilage (e.g., Sox9) and tendon (e.g., $S c x$ ) lineage markers contribute to bony eminence development in the head and trunk such as the angular process of the mandible, deltoid protuberance of the humerus, and great trochanter of the femur [306, 307]. In this way, achieving proper musculoskeletal pattern, structural integration, and linkage between form and function depends on the dynamic ability of tendons and other tissues to detect and respond to biomechanical cues in the local environment. Such developmental plasticity in response to mechanical forces helps shape the jaw skeleton and creates robust muscle attachments. For these reasons, gaining a deeper understanding of the molecular and cellular mechanisms that allow certain tendons to achieve robust osseointegration might some day help enhance the capacity of torn muscle insertions to be re-attached to bone or even regenerated in clinical situations via molecular therapies [308-311].

The primary source of biomechanical forces that contribute to jaw development is embryonic motility. As neuromuscular junctions form, they facilitate spontaneous muscle contractions and cause embryos to move various parts of the skeleton. Presumably, embryonic motility feeds directly into a cascade of molecular and cellular events [137, 233, 312-317] that ultimately enable embryonic form to presage adult function. Birds have served as a well-suited model system for characterizing and quantifying embryonic motility because their relatively large embryos are easily accessed and observed [42, 318-326]. In chicks, the first neuromuscular junctions form in the trunk [327]. Random depolarizations strengthen neuromuscular junctions and mature into cyclic, stereotyped movements of the head, jaws, trunk, and limbs. As Wolff's Law predicts, disruptions to embryonic motility cause widespread and severe musculoskeletal defects. Early paralysis can lead to abnormal joint cavitation [323-331]. Later paralysis can alter the size, shape, extent of ossification, and relative proportions of skeletal elements [303, 305, 332-334]. However, mechanisms that facilitate the relationship between mechanical stimulation and musculoskeletal pattern have for the most part remained obscure.

One mechanically responsive skeletal tissue that appears to be unique to amniotes and plays a critical role in the proper form and function of the jaw is secondary cartilage. Secondary cartilage develops independent of, and subsequent to, the primary cartilaginous skeleton (e.g., the neurocranium and viscerocranium) [3, 51, 335, 336]. Secondary cartilage is found within cranial joints, the sutures of some calvarial bones, the clavicles, antlers of deer, certain ligaments and tendons, and the transient calluses that arise during the healing of broken bones $[42,80,85,233,337-340]$. While secondary cartilage is now limited to birds and mammals, there is some fossil evidence suggesting that a non-avian dinosaur possessed secondary cartilage within the mandibular adductor insertion, raising the possibility that this tissue was also present in archosaurian reptiles more broadly [341, 342].

The formation of secondary cartilage relies on mechanical stimulation and, therefore, the evolutionary presence or absence of secondary cartilage reflects species-specific variation in functional jaw anatomy [336, 339, 343, 344]. In humans, rats, cats, and ducks, secondary cartilage forms at the tendon insertion (i.e., enthesis) of the jaw adductor muscles on the coronoid process (Fig. $3 \mathrm{~h}$, i) [45, $80,233,340,345-350]$. An equivalent secondary cartilage is absent in mice, guinea pigs, chicks, and quails [233, 346-354]. Why secondary cartilage arises at this location in some species and not others is unclear but presumably the underlying mechanisms are responsive to differential forces generated by muscle attachments and jaw movements [42, 137, 233, 312, 313, 315, 350]. In humans and ducks, a robust and protruding secondary cartilage at the coronoid process (that eventually becomes a bony process) provides a broad lateral insertion for the adductor muscles, which enhances leverage and facilitates the sliding motion needed for their specialized modes of feeding [355-362]. Ducks feed via a suction pump mechanism and the levered straining of water. This involves rapid opening and closing of the mandible, which requires sudden acceleration and significant force [356]. Conversely, in quails and chicks, which peck at their food and use the distal tips of their beaks like precise pincers, the adductor muscles insert dorsally and the coronoid process appears as a slight bony ridge (Fig. 3h) [109, 110, 201, 363-367].

As is the case for the jaws of other mammals, secondary cartilage at the human condylar and coronoid processes is required for proper kinetic movement of the temporal-mandibular joint (TMJ) [349, 357, 368, 369]. As described earlier, the TMJ is a uniquely mammalian articulation point for the upper and lower portions of the jaw that is not homologous to the quadrate-articular jaw joint of other vertebrates. The TMJ plays a critical role in 
normal mammalian jaw function and is especially reliant upon the secondary cartilage that covers its articulating surfaces. Secondary cartilage degeneration can often result from trauma, altered mechanical loading, genetic perturbations, and/or hormonal changes, and lead to temporomandibular disorders (TMD). TMD are pervasive human clinical conditions that affect approximately $10 \%$ of the population [370,371] and cause acute pain and suffering for patients [372]. Strategies for molecular and cell-based therapies to restore normal TMJ function impaired by birth defects, injury, or disease can likely benefit by identifying mechanisms that control the development of secondary cartilage. However, mechanisms through which chondrogenic and mechano-responsive factors are regulated, and how changes to the mechanical environment alter expression of these factors remain unclear. Thus, elucidating how secondary cartilage is induced and maintained can provide an important example of how form and function become integrated during the development of the jaw skeleton and also can help shed light on a major unmet clinical need.

The exact nature of the mechanical forces and the downstream molecular mediators that induce and maintain secondary cartilage requires further elaboration. Secondary cartilage fails to form on the duck coronoid process following in ovo paralysis [42, 233], whereas ex vivo culture of embryonic chick jaws shows that cyclic mechanical stimulation is sufficient to promote secondary chondrogenesis at the joint between the quadrate and quadratojugal $[312,313]$. Finite element models, which integrate embryonic motility with species-specific variation in jaw anatomy, have predicted that there are significant qualitative and quantitative differences in the local force environment leading to the presence of secondary cartilage on the duck coronoid process but not on that of the quail [233]. This is based primarily on the observation that in duck, the mandibular adductor inserts on the lateral aspect of the surangular bone, whereas in quail, the insertion is along the dorsal margin. Additionally, the duck insertion is also much more proximal to the jaw joint. Such geometries imply that duck embryos experience substantially higher and more heterogeneous shear stress concentrations at the mandibular adductor insertion, which at their maximum can be 60 timesgreater than those predicted for quail [42]. Also, based on crosssectional area, the embryonic duck mandibular adductor has a maximum contractile force approximately 2.8 times greater than that of quail. Importantly, chimeric "quck" (i.e., quail donor NCM transplanted into a duck host) form a quail-like jaw complex including a transformation of the lateral to dorsal insertion of the mandibular adductor muscle and a corresponding lack of secondary cartilage even though the mandibular adductor muscle itself comes from the duck host.

Thus, the lateral position of the insertion of the mandibular adductor muscle in ducks, which is established as a consequence of patterning by NCM-derived connective tissues [6,233], seemingly creates a combination of axial tension and compression when the adductor muscle contracts and the jaw closes [42, 233]. By comparison, cells in the dorsal insertion of the mandibular adductors in quails likely experience primarily axial tension. These divergent mechanical environments presumably lead to the differential activation of mechano-responsive signaling pathways, which in turn produce cellular changes that in due course dictate the presence or absence of secondary cartilage on the coronoid process. Such results point to the indispensable contributions of NCM to establishing the species-specific form and function in the jaw apparatus. Moreover, some of the pathways required for derivatives of the NCM to adapt and respond to the mechanical environment are beginning to be better understood. Not surprisingly, the ways that developmental programs integrate biomechanical forces and the individual genes and cells that respond to cues from the mechanical environment appear to be context dependant and tissue specific. For example, WNT signaling and the osteocyte-specific WNT inhibitor, sclerostin, have been implicated in mechanosensitive bone remodeling [373-375]. Other mechanisms of mechanotransduction seem to include ligands being freed from the extracellular matrix, signaling through ion channels, changes in focal adhesions, and dynamic rearrangement of the cytoskeleton, among others [233, 302, 376-387].

The quail-duck chimeric system has been especially useful for further pinpointing molecular mechanisms through which jaw morphology and mechanical forces interact [42, 233]. For instance, members and targets of the FGF and TGF $\beta$ signaling pathways are differentially responsive to the species-specific variation in the mechanical force environment of quail versus duck. Both of these pathways are known to play a role during mechanotransduction and chondrogenesis in other biological contexts [388-394], and both pathways are required for secondary chondrogenesis at the coronoid process [42]. Moreover, exogenous FGF and TGF $\beta$ ligands can rescue secondary cartilage in paralyzed duck (again, when no secondary cartilage forms) and also induce cartilage in the quail mandibular adductor insertion, where normally there is none. These important mechanistic insights help explain how species-specific morphology, mechanical forces, and resultant changes in signaling activity become integrated and contribute to musculoskeletal plasticity in the jaw apparatus. In other words, the reason why secondary cartilage forms in some locations in 
some species and not others is likely because of the way embryonic motility interacts with NCM-mediated muscle pattern to create a qualitatively and quantitatively different mechanical force environment. Thus, this example illustrates that while form initially determines function, function can also serve as a forceful regulator of musculoskeletal form in the jaw complex during development and evolution.

\section{Conclusion}

In 1916, E.S. Russell posed the question in his now classic book, Form and Function [18], "Is function the mechanical result of form, or is form merely the manifestation of function or activity? What is the essence of life, organisation or activity? (p.v)." A broad range of experimental strategies across different model systems have revealed that NCM is an essential player in most, if not all, of the decisive events that generate the primary organization of the amniote jaw complex. NCM not only provides the raw materials for the cartilages, bones, and other essential components that comprise the jaws, but NCM is also required for the critical signaling interactions that imbue these tissues with the multidimensional aspects of patterning from which their form is derived. Deficiencies in NCM or perturbing these interactions on the molecular or cellular level alters the form of the jaw complex in profound ways, which illuminates why the jaw complex is both highly evolvable and extremely susceptible to developmental defects [164]. Moreover, while NCM and neighboring epithelia typically collaborate to pattern the cartilages and bones of the jaws, and while NCM and mesodermal mesenchyme work together to pattern the jaw muscles, NCM seems to act as the dominant source of information that gives all of these jaw structures their species-specific size and shape. In this role, NCM is the common denominator that underlies the structural integration of the jaw apparatus, generates species-specific variation, and likely serves as a responsive target of natural selection during evolution [7, 37, 138, 140, 191]. Moreover, NCM has augmented the evolutionary potential (i.e., adaptability) of the pharyngeal and rostral portions of the head and imparts the jaw skeleton with developmental plasticity, as evidenced by the ability of the NCM-derived skeleton to respond to mechanical forces like in the case of secondary cartilage. Initially, the form of the jaw appears to dictate function, but then through embryonic motility, function modulates form. In other words, NCM sets up the speciesspecific "organisation" of the jaw apparatus prior to the onset of muscle "activity." But once jaw activity starts, the form of the skeleton adapts to support its functional needs. The species-specific form of the duck jaw apparatus, especially the geometry of the NCM-mediated muscle attachments, produces mechanical forces that differentially regulate FGF and TGF $\beta$ signaling and cause secondary cartilage to form on the coronoid process. In this regard, NCM not only mediates form but also helps shape the biomechanical environment. Additionally, the patterning abilities and plasticity found in NCM-derived jaw progenitors facilitate seamless integration of form and function during embryonic development and evolution. These same processes are likely perturbed in cases of injury or disease. Overall, elucidating the molecular and cellular mechanisms through which NCM governs the species-specific patterning of cartilage, bone, tendon, and muscle has shed light on the evolutionary integration of form and function in the amniote jaw complex, and in the near future could help remedy an unmet clinical need to repair and regenerate jaw tissues affected by birth defects, disease, or injury.

\begin{abstract}
Abbreviations
BMP: bone morphogenetic proteins; FGF: fibroblast growth factors; FEZ: frontonasal ectodermal zone; FNP: frontonasal process; NCM: neural crest mesenchyme; RA: retinoic acid; SHH: sonic hedgehog; TMD: temporomandibular disorders; TMJ: temporomandibular joint; TGFß: transforming growth factor beta; VEGF: vascular endothelial growth factors; WNT: wingless.

\section{Acknowledgements}

Not applicable.

Summary

1. The amniote jaw skeleton evolved as a composite structure.

2. Amniote jaws have species-specific sizes and shapes that function in diverse dietary and predatory niches.

3. Derivatives of all three germ layers must communicate seamlessly to produce a jaw complex that is structurally and functionally integrated.

4. Neural crest mesenchyme dictates the species-specific size and shape of the jaw skeleton and patterns the supporting musculature.

5. The formation and growth of jaw tissues are influenced by the mechanical environment.
\end{abstract}

\section{Authors' contributions}

The authors KCW and RAS co-wrote the manuscript. Both authors read and approved the final manuscript.

\section{Funding}

This work was supported in part by the Eunice Kennedy Shriver National Institute of Child Health and Human Development (NICHD) T32 HD007470 and the National Institute of Dental and Craniofacial Research (NIDCR) F31 DE024405 to K.C.W.; and NIDCR R01 DE016402 and R01 DE025668 to R.A.S. These funders had no role in any aspect of the study or in writing the manuscript.

\section{Availability of data and materials}

Not applicable.

Ethics approval and consent to participate

Not applicable.

Consent for publication

Not applicable.

Competing interests

The authors declare that they have no competing interests. 


\section{Author details}

1 Department of Orthopaedic Surgery, University of California at San Francisco, 513 Parnassus Avenue, S-1 161, Box 0514, San Francisco, CA 94143-0514, USA. ${ }^{2}$ Present Address: Department of Genetics, Harvard Medical School, Orthopaedic Research Laboratories, Children's Hospital Boston, Boston, MA 02115, USA

Received: 13 December 2018 Accepted: 22 July 2019

Published online: 12 August 2019

\section{References}

1. Smith KK. The form of the feeding apparatus in terrestrial vertebrates: Studies of adaptation and constraint. In: Hanken J, Hall BK, editors. The skull, vol. 3. Chicago: University of Chicago Press; 1993. p. 150-96.

2. Zusi RL. Patterns of diversity in the avian skull. In: Hanken J, Hall BK, editors. The skull, vol. 2. Chicago: University of Chicago Press; 1993. p. 391-437.

3. de Beer GR. The development of the vertebrate skull. Chicago: University of Chicago Press; 1937.

4. Sánchez-Villagra MR, Smith KK. Diversity and evolution of the marsupial mandibular angular process. Journal of Mammalian Evolution. 1997:4:119-44.

5. Tokita M, Nakayama T, Schneider RA, Agata K. Molecular and cellular changes associated with the evolution of novel jaw muscles in parrots. Proc Biol Sci. 2013;280:20122319.

6. Tokita M, Schneider RA. Developmental origins of species-specific muscle pattern. Developmental Biology. 2009;331:311-25.

7. Schneider RA. Regulation of jaw length during development, disease, and evolution. Curr Top Dev Biol. 2015:115:271-98.

8. Lee MSY, Bell GL, Caldwell MW. The origin of snake feeding. Nature. 1999:400:655-9.

9. Hoso M, Asami T, Hori M. Right-handed snakes: convergent evolution of asymmetry for functional specialization. Biol Lett. 2007;3:169-72.

10. Danaisawadi P, Asami T, Ota H, Sutcharit C, Panha S. A snail-eating snake recognizes prey handedness. Sci Rep. 2016;6:23832.

11. Benkman CW. Are the ratios of bill crossing morphs in crossbills the result of frequency-dependent selection? Evol Ecol. 1996;10:119-26.

12. Benkman CW, Lindholm AK. The advantages and evolution of a morphological novelty. Nature. 1991;349:519-20.

13. Thompson JN. Coevolution, local adaptation and ecological speciation. Mol Ecol. 2016;25:5608-10.

14. Naples VL. Morphology, evolution and function of feeding in the giant anteater (Myrmecophaga tridactyla). J Zool. 1999;249:19-41.

15. Goodrich ES. Studies on the structure and development of vertebrates. Chicago: University of Chicago Press; 1930.

16. de Beer GR. Embryology and evolution. Oxford: Clarendon Press; 1930.

17. Appel TA. The Cuvier-Geoffroy Debate: French biology in the decade before darwin. Oxford: Oxford University Press; 1987.

18. Russell ES. Form and function: a contribution to the history of animal morphology. London: John Murray Publishers Ltd.; 1916.

19. Noden D, Schneider RA. Neural crest cells and the community of plan for craniofacial development: Historical debates and current perspectives. In: Saint-Jeannet J-P, editor. Neural crest induction and differentiation, vol. 589. Georgetown: Landes Bioscience; 2006. p. 1-23.

20. Owen R. Lectures on the comparative anatomy and physiology of the invertebrate animals: delivered at the royal college of surgeons. London: Longman, Brown, Green, and Longmans; 1843.

21. Owen R. On the Archetype and Homologies of the Vertebrate Skeleton. London: John Van Voorst, Paternoster Row; 1848.

22. Kuratani S. Craniofacial development and the evolution of the vertebrates: the old problems on a new background. Zool Sci. 2005;22:1-19.

23. Huxley TH. On the theory of the vertebrate skull. Proc R Soc London. 1858;9:381-457

24. Lankester ER. On the use of the term homology in modern zoology, and the distinction between homogenetic and homoplastic agreements. Ann Magaz Nat History. 1870;4:35-43.

25. Goodrich ES. Metameric segmentation and homology. Q J Microscop Sci. 1913:59:227-48.
26. Kingsbury BF. Branchiomerism and the theory of head segmentation. J Morphol Physiol. 1926;42:83-109.

27. Romer AS. The vertebrate as dual animal-somatic and visceral. In: Dobzhansky T, Hecht MK, Steere WC, editors. Evolutionary biology, vol. 6. New York: Appleton-Century-Crofts; 1972. p. 121-56.

28. Jarvik E. Basic structure and evolution of vertebrates. London: Academic Press; 1980.

29. Jollie M. Segment theory and the homologizing of cranial bones. Am Nat. 1981:118:785-802.

30. Jollie M. The vertebrate head: segmented or a single morphological structure? J Vertebr Paleontol. 1984:4:320-9.

31. Mitgutsch C. On Carl Gegenbaur's theory on head metamerism and the selection of taxa for comparisons. Theory Biosci. 2003:122:204-29.

32. Olsson L, Ericsson R, Cerny R. Vertebrate head development: segmentation, novelties, and homology. Theory Biosci. 2005;124:145-63.

33. Kuratani S. Evolution of the vertebrate jaw from developmental perspectives. Evol Dev. 2012;14:76-92.

34. Reichert C. Über die Visceralbogen der Wirbeltiere im Allgemeinen und deren Metamorphosen bei den Vögeln und Säugetieren. Archiv für Anatomie, Physiologie und wissenschaftliche Medicin. 1837;1837:120-222.

35. Huxley TH. Lectures on the elements of comparative anatomy. London: J. Churchill and Sons; 1864.

36. Gould SJ. Ontogeny and phylogeny. Cambridge: Harvard University Press; 1977.

37. Schneider RA. Neural crest and the origin of species-specific pattern. Genesis. 2018;56:e23219.

38. Ealba EL, Jheon AH, Hall J, Curantz C, Butcher KD, Schneider RA. Neural crest-mediated bone resorption is a determinant of species-specific jaw length. Dev Biol. 2015:408:151-63.

39. Fish JL, Sklar RS, Woronowicz KC, Schneider RA. Multiple developmental mechanisms regulate species-specific jaw size. Development. 2014;141:674-84

40. Hall J, Jheon AH, Ealba EL, Eames BF, Butcher KD, Mak SS, Ladher R, Alliston T, Schneider RA. Evolution of a developmental mechanism: species-specific regulation of the cell cycle and the timing of events during craniofacial osteogenesis. Dev Biol. 2014;385:380-95.

41. Linde-Medina M, Hallgrimsson B, Marcucio R. Beyond cell proliferation in avian facial morphogenesis. Dev Dyn. 2016:245:190-6.

42. Woronowicz KC, Gline SE, Herfat ST, Fields AJ, Schneider RA. FGF and TGF $\beta$ signaling link form and function during jaw development and evolution. Dev Biol. 2018;444(Suppl 1):S219-36.

43. Hughes AJ, Miyazaki H, Coyle MC, Zhang J, Laurie MT, Chu D, Vavrušová Z, Schneider RA, Klein OD, Gartner ZJ. Engineered tissue folding by mechanical compaction of the mesenchyme. Dev Cell. 2018:44:165-78.

44. Jollie M. Chordate morphology. New York: Reinhold Publishing Corporation; 1962.

45. Moore WJ. The mammalian skull. Cambridge: Cambridge University Press; 1981

46. Smith MM, Hall BK. A development model for evolution of the vertebrate exoskeleton and teeth: The role of cranial and trunk neural crest. In: Max HK, editor. Evolutionary biology, vol. 27. New York: Plenum Press; 1993. p. 387-449.

47. Kuratani S. The neural crest and origin of the neurocranium in vertebrates. Genesis. 2018;56:e23213.

48. Gegenbaur C, Bell FJ, Lankester ER. Elements of comparative anatomy. London: Macmillan and Co.; 1878.

49. Reynolds SH. The Vertebrate Skeleton. Cambridge: Cambridge University Press; 1897

50. Hirasawa T, Kuratani S. Evolution of the vertebrate skeleton: morphology, embryology, and development. Zool Lett. 2015;1:2.

51. Patterson C. Cartilage bones, dermal bones, and membrane bones, or the exoskeleton versus the endoskeleton. In: Andrews S, Miles R, Walker A, editors. Problems in vertebrate evolution, vol. 4. London: Academic Press; 1977. p. 77-121.

52. ReifWE. Evolution of dermal skeleton and dentition in vertebrates: the odontode regulation theory. Evol Biol. 1982;15:287-368. 
53. Smith MM, Hall BK. Development and evolutionary origins of vertebrate skeletogenic and odontogenic tissues. Biol Rev Camb Philos Soc. 1990;65:277-373.

54. Couly GF, Coltey PM, Le Douarin NM. The triple origin of skull in higher vertebrates: a study in quail-chick chimeras. Development. 1993;117:409-29.

55. Noden DM, Trainor PA. Relations and interactions between cranial mesoderm and neural crest populations. J Anat. 2005;207:575-601.

56. Square $T$, Jandzik D, Romasek $M$, Cerny $R$, Medeiros DM. The origin and diversification of the developmental mechanisms that pattern the vertebrate head skeleton. Dev Biol. 2017:427:219-29.

57. Platt JB. Ectodermic origin of the cartilages of the head. Anat Anz. 1893:8:506-9.

58. Landacre FL. The fate of the neural crest in the head of the urodeles. J Comp Neurol. 1921;33:1-43.

59. Stone LS. Further experiments on the extirpation and transplantation of mesectoderm in Amblystoma punctatum. J Exp Zool. 1926;44:95-131.

60. Stone LS. Experiments showing the role of migrating neural crest (mesectoderm) in the formation of head skeleton and loose connective tissue in Rana palustris. Wilhelm Roux's Archiv für Entwicklungsmechanik der Organismen. 1929;118:40-77.

61. de Beer GR. The differentiation of neural crest cells into visceral cartilages and odontoblasts in Amblystoma, and a re-examination of the germ-layer theory. Proc R Soc Lond B. 1947;134:377-98.

62. Noden DM. The control of avian cephalic neural crest cytodifferentiation. I. Skeletal and connective tissues. Dev Biol. 1978;67:296-312.

63. Noden DM. Interactions and fates of avian craniofacial mesenchyme. Development. 1988;103:121-40.

64. Gross JB, Hanken J. Review of fate-mapping studies of osteogenic cranial neural crest in vertebrates. Developmental Biology. 2008;317:389-400.

65. Kuratani S, Ahlberg PE. Evolution of the vertebrate neurocranium: problems of the premandibular domain and the origin of the trabecula. Zool Lett. 2018:4:1.

66. Morriss-Kay GM. Derivation of the mammalian skull vault. J Anat. 2001:199:143-51.

67. Jiang X, Iseki S, Maxson RE, Sucov HM, Morriss-Kay GM. Tissue origins and interactions in the mammalian skull vault. Dev Biol. 2002;241:106-16.

68. McBratney-Owen B, Iseki S, Bamforth SD, Olsen BR, Morriss-Kay GM Development and tissue origins of the mammalian cranial base. Dev Biol. 2008:322:121-32.

69. Yoshida T, Vivatbutsiri P, Morriss-Kay G, Saga Y, Iseki S. Cell lineage in mammalian craniofacial mesenchyme. Mech Dev. 2008;125:797-808.

70. Matsuoka T, Ahlberg PE, Kessaris N, lannarelli P, Dennehy U, Richardson WD, McMahon AP, Koentges G. Neural crest origins of the neck and shoulder. Nature. 2005;436(7049):347-55. https://doi.org/10.1038/natur e03837.

71. Evans DJ, Noden DM. Spatial relations between avian craniofacial neural crest and paraxial mesoderm cells. Dev Dyn. 2006;235:1310-25.

72. Tabler JM, Rigney MM, Berman GJ, Gopalakrishnan S, Heude E, Al-Lam HA, Yannakoudakis BZ, Fitch RD, Carter C, Vokes S, Liu KJ, Tajbakhsh S, Egnor SR, Wallingford JB. Cilia-mediated Hedgehog signaling controls form and function in the mammalian larynx. Elife. 2017. https://doi. org/10.7554/eLife.19153.

73. Noden DM. Origins and patterning of craniofacial mesenchymal tissues. J Craniofac Genet Dev Biol Suppl. 1986;2:15-31.

74. Sefton EM, Piekarski N, Hanken J. Dual embryonic origin and patterning of the pharyngeal skeleton in the axolotl (Ambystoma mexicanum). Evol Dev. 2015:17(3):175-84

75. Davidian A, Malashichev Y. Dual embryonic origin of the hyobranchial apparatus in the Mexican axolotl (Ambystoma mexicanum). Int J Dev Biol. 2013;57(11-12):821-8.

76. Moss ML. Comparative anatomy of vertebrate dermal bone and teeth. I The epidermal co-participation hypothesis. Acta Anat. 1968;71:178-208.

77. Le Lievre CS, Le Douarin NM. Mesenchymal derivatives of the neural crest: analysis of chimaeric quail and chick embryos. J Embryol Exp Morphol. 1975;34:125-54.

78. Thomson KS. The neural crest and the morphogenesis and evolution of the dermal skeleton in vertebrates. In: Maderson PFA, editor.
Developmental and evolutionary aspects of the neural crest. New York: Wiley; 1987. p. 301-38.

79. Helms JA, Schneider RA. Cranial skeletal biology. Nature. 2003;423:326-31

80. Hall BK. Bones and cartilage: developmental and evolutionary skeletal biology. 2nd ed. Amsterdam: Elsevier/Academic Press; 2015

81. Hall BK, Miyake T. The membranous skeleton: the role of cell condensations in vertebrate skeletogenesis. Anat Embryol. 1992;186:107-24.

82. Beresford WA. Cranial skeletal tissues: Diversity and evolutionary trends. In: Hanken J, Hall BK, editors. The skull, vol. 2. Chicago: University of Chicago Press; 1993. p. 69-130.

83. Hall BK. Cartilage. New York: Academic Press; 1983.

84. Thorogood P. Morphogenesis of cartilage. In: Hall BK, editor. Cartilage, vol. 2. New York: Academic Press, Inc.; 1983. p. 223-53.

85. Schneider RA, Helms JA. Development and regeneration of the musculoskeletal system. Curr Opin Orthop. 1998;9:20-4.

86. Graham A. Development of the pharyngeal arches. Am J Med Genetics A. 2003;119:251-6.

87. Shone V, Graham A. Endodermal/ectodermal interfaces during pharyngeal segmentation in vertebrates. J Anat. 2014:225:479-91.

88. Allis EP. Are the polar and trabecular cartilages of vertebrate embryos the pharyngeal elements of the mandibular and premandibular arches? J Anat. 1923;58:37-51.

89. Allis EP. In further explanation of my theory of the polar and trabecular cartilages. J Anat. 1924:59:333-5.

90. Allis EP. Concerning the development of the prechordal portion of the vertebrate head. J Anat. 1938;72:584-607.

91. Kuratani S. Cephalic neural crest cells and the evolution of craniofacial structures in vertebrates: morphological and embryological significance of the premandibular-mandibular boundary. Zoology. 2005:108:13-25.

92. Cerny R, Lwigale P, Ericsson R, Meulemans D, Epperlein HH, BronnerFraser M. Developmental origins and evolution of jaws: new interpretation of "maxillary" and "mandibular". Dev Biol. 2004;276:225-36.

93. Kuratani S, Adachi N, Wada N, Oisi Y, Sugahara F. Developmental and evolutionary significance of the mandibular arch and prechordal/premandibular cranium in vertebrates: revising the heterotopy scenario of gnathostome jaw evolution. J Anat. 2013;222:41-55.

94. Miyashita T. Fishing for jaws in early vertebrate evolution: a new hypothesis of mandibular confinement. Biol Rev. 2016:91:611-57.

95. Smith KK. The evolution of the mammalian pharynx. Zool J Linnean Soc. 1992:104:313-49.

96. Gans C, Northcutt RG. Neural crest and the origin of vertebrates: a new head. Science. 1983;220:268-74.

97. Northcutt RG. The new head hypothesis revisited. J Exp Zool Part B. 2005;304B:274-97.

98. Northcutt RG, Gans C. The genesis of neural crest and epidermal placodes. Q Rev Biol. 1983;58:1-27.

99. Carroll RL. Vertebrate paleontology and evolution. New York: W. H. Freeman and Co.; 1988.

100. Romer AS. Osteology of the reptiles. Chicago: University of Chicago Press; 1956

101. Rieppel O. The homology of the laterosphenoid bone in snakes. Herpetologica. 1976;32:426-9.

102. Smith KK, Schneider RA. Have gene knockouts caused evolutionary reversals in the mammalian first arch? BioEssays. 1998;20:245-55.

103. Holliday C, Witmer L. The epipterygoid of Crocodyliforms and its significance for the evolution of the orbitotemporal region of Eusuchians. J Vertebr Paleontol. 2009;29:715-33.

104. Kingsley JS. The vertebrate skeleton from the developmental standpoint. Philadelphia: P. Blakiston's Son \& Co.; 1925.

105. Kavumpurath S, Hall BK. Lack of either chondrocyte hypertrophy or osteogenesis in Meckel's cartilage of the embryonic chick exposed to epithelia and to thyroxine in vitro. J Craniofac Genet Dev Biol. 1990;10:263-75.

106. Ekanayake S, Hall BK. Hypertrophy is not a prerequisite for type $X$ collagen expression or mineralization of chondrocytes derived from cultured chick mandibular ectomesenchyme. Int J Exp Biol. 1994:38:683-94

107. Eames BF, Sharpe PT, Helms JA. Hierarchy revealed in the specification of three skeletal fates by Sox9 and Runx2. Dev Biol. 2004:274:188-200. 
108. Parker WK. On the structure and development of the bird's skull. Trans Linnean Soc London. 1879;1:99-151.

109. Shufeldt RW. Osteology of Birds. Albany: University of the State of New York; 1909.

110. Chamberlain FW. Atlas of avian anatomy: osteology, arthrology, myology. East Lansing: Michigan State College, Agricultural Experiment Station; 1943.

111. Presley R, Steel FLD. On the homology of the alisphenoid. J Anat. 1976:121:441-59.

112. Presley R. Alisphenoid equivalents in placentals, marsupials, monotremes and fossils. Nature. 1981;294:668-70.

113. Maier W. Ala temporalis and alisphenoid in therian mammals. In: Splechtha $\mathrm{H}$, Hilgers $\mathrm{H}$, editors. Trends in vertebrate morphology: proceedings of the 2nd international symposium on vertebrate morphology (1986). New York: Gustav Fischer Verlag; 1989. p. 396-400.

114. Schneider RA. Neural crest can form cartilages normally derived from mesoderm during development of the avian head skeleton. Dev Biol. 1999;208:441-55.

115. Crompton AW, Parker P. Evolution of the mammalian masticatory apparatus. Am Sci. 1978;66:192-201.

116. Gaupp E. Die Reichertsche Theorie (Hammer-, Amboss- und Kieferfrage). Archiv für Anatomie und Entwicklungsgeschichte. 1913;1912:1-416.

117. Anthwal N, Joshi L, Tucker AS. Evolution of the mammalian middle ear and jaw: adaptations and novel structures. J Anat. 2013;222:147-60.

118. Tucker AS. Major evolutionary transitions and innovations: the tympanic middle ear. Phil Trans R Soc London B Biol Sci. 2017;372:20150483.

119. Amin S, Tucker AS. Joint formation in the middle ear: lessons from the mouse and guinea pig. Dev Dyn. 2006;235:1326-33.

120. Anthwal N, Urban DJ, Luo ZX, Sears KE, Tucker AS. Meckel's cartilage breakdown offers clues to mammalian middle ear evolution. Nat Eco Evol. 2017;1:93.

121. Crompton AW. The evolution of the mammalian jaw. Evolution. 1963;17:431-9.

122. Davis DD. Origin of the mammalian feeding mechanism. Am Zool. 1961;1:229-34.

123. Lautenschlager S, Gill PG, Luo ZX, Fagan MJ, Rayfield EJ. The role of miniaturization in the evolution of the mammalian jaw and middle ear. Nature. 2018:561:533-7.

124. Takechi M, Kuratani S. History of studies on mammalian middle ear evolution: a comparative morphological and developmental biology perspective. J Exp Zool B Mol Dev Evol. 2010;314:417-33.

125. Rowe T. Coevolution of the mammalian middle ear and neocortex. Science. 1996:273:651.

126. Allin EF. Evolution of the mammalian middle ear. J Morphol. 1975; 147:403-37.

127. Smith KK. An electromyographic study of the function of the jaw adducting muscles in Varanus exanthematicus (Varanidae). J Morphol. 1982:173:137-58.

128. Noden DM, Francis-West P. The differentiation and morphogenesis of craniofacial muscles. Dev Dyn. 2006:235:1194-218.

129. Herring SW. Functional morphology of mammalian mastication. Am Zool. 1993:33:289-99.

130. Noden DM. Vertebrate craniofacial development: the relation between ontogenetic process and morphological outcome. Brain Behav Evol. 1991;38:190-225

131. Lautenschlager S, Gill P, Luo ZX, Fagan MJ, Rayfield EJ. Morphological evolution of the mammalian jaw adductor complex. Biol Rev Camb Philos Soc. 2017;92:1910-40.

132. Hall WG, Williams CL. Suckling isn't feeding, or is it? A search for developmental continuities. Adv Study Behav. 1983;13:219-54.

133. Apostolakos J, Durant TJ, Dwyer CR, Russell RP, Weinreb JH, Alaee F, Beitzel K, McCarthy MB, Cote MP, Mazzocca AD. The enthesis: a review of the tendon-to-bone insertion. Mus Ligaments Tendons J. 2014;4:333-42.

134. Zelzer E, Blitz E, Killian ML, Thomopoulos S. Tendon-to-bone attachment: from development to maturity. Birth Defects Res C Embr Today. 2014;102:101-12.

135. Subramanian A, Schilling TF. Tendon development and musculoskeletal assembly: emerging roles for the extracellular matrix. Development. 2015:142:4191-204
136. Benjamin M, Ralphs JR. Fibrocartilage in tendons and ligaments —an adaptation to compressive load. J Anat. 1998;193:481-94.

137. Carter DR, Beaupré GS. Skeletal function and form: mechanobiology of skeletal development, aging, and regeneration. Cambridge: Cambridge University Press; 2007.

138. Fish JL, Schneider RA. Chapter 6-neural crest-mediated tissue interactions during craniofacial development: the origins of species-specific pattern. In: Trainor PA, editor. Neural crest cells. Boston: Academic Press; 2014. p. 101-24.

139. Schneider RA, Hu D, Helms JA. From head to toe: conservation of molecular signals regulating limb and craniofacial morphogenesis. Cell Tissue Res. 1999:296:103-9.

140. Schneider RA. Developmental mechanisms facilitating the evolution of bills and quills. J Anat. 2005;207:563-73.

141. Hu D, Marcucio RS, Helms JA. A zone of frontonasal ectoderm regulates patterning and growth in the face. Development. 2003;130:1749-58.

142. Szabo-Rogers HL, Smithers LE, Yakob W, Liu KJ. New directions in craniofacial morphogenesis. Dev Biol. 2010;341:84-94.

143. Hu D, Marcucio RS. Neural crest cells pattern the surface cephalic ectoderm during FEZ formation. Dev Dyn. 2012;241:732-40.

144. Young NM, Hu D, Lainoff AJ, Smith FJ, Diaz R, Tucker AS, Trainor PA, Schneider RA, Hallgrimsson B, Marcucio RS. Embryonic bauplans and the developmental origins of facial diversity and constraint. Development. 2014;141:1059-63.

145. Cordero DR, Schneider RA, Helms JA. Morphogenesis of the face. In: Lin KY, Ogle RC, Jane JA, editors. Craniofacial surgery: science \& surgical technique. Philadelphia: W. B. Saunders Company; 2002. p. 75-83.

146. Shkoukani MA, Chen M, Vong A. Cleft lip_a comprehensive review. Front Pediatr. 2013:1:53.

147. Chong HJ, Young NM, Hu D, Jeong J, McMahon AP, Hallgrimsson B, Marcucio RS. Signaling by SHH rescues facial defects following blockade in the brain. Dev Dyn. 2012;241:247-56.

148. Hu D, Young NM, Li X, Xu Y, Hallgrimsson B, Marcucio RS. A dynamic Shh expression pattern, regulated by $\mathrm{SHH}$ and BMP signaling, coordinates fusion of primordia in the amniote face. Development. 2015:142:567-74

149. Young NM, Chong HJ, Hu D, Hallgrimsson B, Marcucio RS. Quantitative analyses link modulation of sonic hedgehog signaling to continuous variation in facial growth and shape. Development. 2010;137:3405-9.

150. Li X, Young NM, Tropp S, Hu D, Xu Y, Hallgrimsson B, Marcucio RS. Quantification of shape and cell polarity reveals a novel mechanism underlying malformations resulting from related FGF mutations during facial morphogenesis. Hum Mol Genet. 2013;22:5160-72.

151. Smith FJ, Percival CJ, Young NM, Hu D, Schneider RA, Marcucio RS, Hallgrimsson B. Divergence of craniofacial developmental trajectories among avian embryos. Dev Dyn. 2015;244(9):1158-67.

152. Gorlin RJ, Cohen MM, Levin LS. Syndromes of the head and neck. 3rd ed. New York: Oxford University Press; 1990.

153. Theveneau E, Mayor R. Neural crest delamination and migration: from epithelium-to-mesenchyme transition to collective cell migration. Dev Biol. 2012:366:34-54

154. Baker CV, Bronner-Fraser M. The origins of the neural crest. Part I: embryonic induction. Mech Dev. 1997:69:3-11.

155. Bronner-Fraser M. Neural crest cell formation and migration in the developing embryo. FASEB J. 1994:8:699-706.

156. Hörstadius S. The neural crest: its properties and derivatives in the light of experimental research. London: Oxford University Press; 1950.

157. Selleck MA, Bronner-Fraser M. The genesis of avian neural crest cells: a classic embryonic induction. Proc Natl Acad Sci. 1996;93:9352-7.

158. Selleck MAJ, Bronner-Fraser M. Origins of the avian neural crest: the role of neural plate-epidermal interactions. Development. 1995;121:525-38.

159. Tosney KW. The segregation and early migration of cranial neural crest cells in the avian embryo. Dev Biol. 1982;89:13-24.

160. Köntges $G$, Lumsden A. Rhombencephalic neural crest segmentation is preserved throughout craniofacial ontogeny. Development. 1996;122:3229-42.

161. Noden DM. The embryonic origins of avian cephalic and cervical muscles and associated connective tissues. Am J Anat. 1983;168:257-76.

162. Dupin E, Calloni GW, Le Douarin NM. The cephalic neural crest of amniote vertebrates is composed of a large majority of precursors endowed 
with neural, melanocytic, chondrogenic and osteogenic potentialities. Cell Cycle. 2010;9:238-49.

163. Le Lièvre CS. Participation of neural crest-derived cells in the genesis of the skull in birds. J Embryol Exp Morphol. 1978;47:17-37.

164. Jheon AH, Schneider RA. The cells that fill the bill: neural crest and the evolution of craniofacial development. J Dent Res. 2009;88:12-21.

165. McLennan R, Schumacher LJ, Morrison JA, Teddy JM, Ridenour DA, Box AC, Semerad CL, Li H, McDowell W, Kay D, Maini PK, Baker RE, Kulesa PM. Neural crest migration is driven by a few trailblazer cells with a unique molecular signature narrowly confined to the invasive front. Development. 2015;142:2014-25.

166. Olesnicky Killian EC, Birkholz DA, Artinger KB. A role for chemokine signaling in neural crest cell migration and craniofacial development. Dev Biol. 2009;333:161-72.

167. Creuzet S, Schuler B, Couly G, Le Douarin NM. Reciprocal relationships between Fgf8 and neural crest cells in facial and forebrain development. Proc Natl Acad Sci. 2004;101:4843-7.

168. McLennan R, Schumacher $L$, Morrison JA, Teddy JM, Ridenour DA, Box AC, Semerad CL, Li H, McDowell W, Kay D, Maini PK, Baker RE, Kulesa PM. VEGF signals induce trailblazer cell identity that drives neural crest migration. Dev Biol. 2015;407:12-25.

169. Shellard A, Mayor R. Chemotaxis during neural crest migration. Semin Cell Dev Biol. 2016;55:111-8

170. Trainor PA, Sobieszczuk D, Wilkinson D, Krumlauf R. Signalling between the hindbrain and paraxial tissues dictates neural crest migration pathways. Development. 2002;129:433-42.

171. Kulesa P, Ellies DL, Trainor PA. Comparative analysis of neural crest cell death, migration, and function during vertebrate embryogenesis. Dev Dyn. 2004;229:14-29.

172. Roycroft A, Mayor R. Molecular basis of contact inhibition of locomotion. Cell Mol Life Sci. 2016:73:1119-30

173. Minoux M, Rijli FM. Molecular mechanisms of cranial neural crest cell migration and patterning in craniofacial development. Development. 2010;137:2605-21.

174. Gammill LS, Gonzalez C, Bronner-Fraser M. Neuropilin 2/semaphorin 3F signaling is essential for cranial neural crest migration and trigeminal ganglion condensation. Dev Neurobiol. 2007;67:47-56.

175. Golding JP, Trainor P, Krumlauf R, Gassmann M. Defects in pathfinding by cranial neural crest cells in mice lacking the neuregulin receptor ErbB4. Nat Cell Biol. 2000;2:103-9.

176. Baroffio A, Dupin E, Le Douarin NM. Clone-forming ability and differentiation potential of migratory neural crest cells. Proc Natl Acad Sci. 1988:85:5325-9.

177. Bronner-Fraser M, Fraser SE. Cell lineage analysis reveals multipotency of some avian neural crest cells. Nature. 1988;335:161-4.

178. Stemple DL, Anderson DJ. Isolation of a stem cell for neurons and glia from the mammalian neural crest. Cell. 1992;71:973-85.

179. Henion PD, Weston JA. Timing and pattern of cell fate restrictions in the neural crest lineage. Development. 1997:124:4351-9.

180. Luo R, Gao J, Wehrle-Haller B, Henion PD. Molecular identification of distinct neurogenic and melanogenic neural crest sublineages. Development. 2003;130:321-30.

181. Krispin S, Nitzan E, Kassem Y, Kalcheim C. Evidence for a dynamic spatiotemporal fate map and early fate restrictions of premigratory avian neural crest. Development. 2010;137:585-95.

182. Sieber-Blum M. Commitment of neural crest cells to the sensory neuron lineage. Science. 1989;243:1608-11.

183. Baggiolini A, Varum S, Mateos JM, Bettosini D, John N, Bonalli M, Ziegler U, Dimou L, Clevers H, Furrer R, Sommer L. Premigratory and migratory neural crest cells are multipotent in vivo. Cell Stem Cell. 2015;16:314-22.

184. Martik ML, Bronner ME. Regulatory logic underlying diversification of the neural crest. Trends Genet. 2017:33:715-27.

185. Betancur P, Bronner-Fraser M, Sauka-Spengler T. Assembling neural crest regulatory circuits into a gene regulatory network. Annu Rev Cell Dev Biol. 2010;26:581-603.

186. Sauka-Spengler T, Bronner-Fraser M. A gene regulatory network orchestrates neural crest formation. Nat Rev Mol Cell Biol. 2008;9:557-68.

187. Sauka-Spengler T, Meulemans D, Jones M, Bronner-Fraser M. Ancient evolutionary origin of the neural crest gene regulatory network. Dev Cell. 2007:13:405-20.
188. Simoes-Costa M, Tan-Cabugao J, Antoshechkin I, Sauka-Spengler T, Bronner ME. Transcriptome analysis reveals novel players in the cranial neural crest gene regulatory network. Genome Res. 2014;24:281-90.

189. Jones NC, Lynn ML, Gaudenz K, Sakai D, Aoto K, Rey JP, Glynn EF, Ellington L, Du C, Dixon J, Dixon MJ, Trainor PA. Prevention of the neurocristopathy Treacher Collins syndrome through inhibition of p53 function. Nat Med. 2008:14:125-33.

190. Kissel P, André JM, Jacquier A. The neurocristopathies. New York: Masson Publisher; 1981 .

191. Sanchez-Villagra MR, Geiger M, Schneider RA. The taming of the neural crest: a developmental perspective on the origins of morphological covariation in domesticated mammals. R Soc Open Sci. 2016;3:160107.

192. Bancroft M, Bellairs R. Placodes of the chick embryo studied by SEM. Anat Embryol. 1977;151:97-108.

193. Couly G, Le Douarin NM. The fate map of the cephalic neural primordium at the presomitic to the 3-somite stage in the avian embryo. Development. 1988;103:101-13.

194. Webb JF, Noden DM. Ectodermal placodes: contributions to the development of the vertebrate head. Am Zool. 1993;33:434-47.

195. Francis-West PH, Ladher RK, Schoenwolf GC. Development of the sensory organs. Sci Prog. 2002;85:151-73.

196. Baker CV, Stark MR, Marcelle C, Bronner-Fraser M. Competence, specification and induction of Pax-3 in the trigeminal placode. Development. 1999:126:147-56.

197. Hamburger V, Narayanan $\mathrm{CH}$. Effects of the deafferentation of the trigeminal area on the motility of the chick embryo. J Exp Zool. 1969:170:411-26.

198. Kuratani S, Tanaka S. Peripheral development of avian trigeminal nerves. Am J Anat. 1990:187:65-80.

199. Noden DM. Somatotopic and functional organization of the avian trigeminal ganglion: an HRP analysis in the hatchling chick. J Comp Neurol. 1980;190:405-28.

200. Kingsbury JW, Allen VG, Rotheram BA. The histological structure of the beak in the chick. Anat Rec. 1953;116:95-115.

201. Lucas AM, Stettenheim PR. Avian anatomy: integument. Washington, DC: United States Department of Agriculture; 1972.

202. Romanoff AL. The avian embryo. New York: The Macmillan Company; 1960.

203. Hamilton HL. Lillie's development of the chick: an introduction to embryology. 3rd ed. New York: Holt, Rinehart and Winston; 1965.

204. Yasui K, Hayashi Y. Morphogenesis of the beak of the chick embryo: histological, histochemical and autoradiographic studies. Embryologia. 1967;10:42-74.

205. Noden DM, Marcucio R, Borycki AG, Emerson CP Jr. Differentiation of avian craniofacial muscles: I. Patterns of early regulatory gene expression and myosin heavy chain synthesis. Dev Dyn. 1999;216:96-112.

206. Couly GF, Coltey PM, Le Douarin NM. The developmental fate of the cephalic mesoderm in quail-chick chimeras. Development. 1992:114:1-15.

207. Couly G, Coltey P, Eichmann A, Le Douarin NM. The angiogenic potentials of the cephalic mesoderm and the origin of brain and head blood vessels. Mech Dev. 1995;53:97-112.

208. Jotereau FV, Le Douarin NM. The development relationship between osteocytes and osteoclasts: a study using the quail-chick nuclear marker in endochondral ossification. Developmental Biology. 1978;63:253-65.

209. Noden DM. Origins and patterning of avian craniofacial muscles. Dev Biol. 1986;116:347-56.

210. Noden DM. Origins and assembly of avian embryonic blood vessels. Ann N Y Acad Sci. 1990:588:236-49.

211. Ruberte J, Carretero A, Navarro M, Marcucio RS, Noden D. Morphogenesis of blood vessels in the head muscles of avian embryo: spatial, temporal, and VEGF expression analyses. Dev Dyn. 2003;227:470-83.

212. Noden DM. The role of the neural crest in patterning of avian cranial skeletal, connective, and muscle tissues. Dev Biol. 1983;96:144-65.

213. Mootoosamy RC, Dietrich S. Distinct regulatory cascades for head and trunk myogenesis. Development. 2002;129:573-83.

214. Shih HP, Gross MK, Kioussi C. Cranial muscle defects of Pitx2 mutants result from specification defects in the first branchial arch. Proc Natl Acad Sci. 2007:104:5907-12. 
215. Tajbakhsh S, Rocancourt D, Cossu G, Buckingham M. Redefining the genetic hierarchies controlling skeletal myogenesis: pax-3 and Myf-5 act upstream of MyoD. Cell. 1997:89:127-38.

216. Tzahor E, Kempf H, Mootoosamy RC, Poon AC, Abzhanov A, Tabin CJ, Dietrich S, Lassar AB. Antagonists of WNT and BMP signaling promote the formation of vertebrate head muscle. Genes Dev. 2003;17:3087-99.

217. Diogo R, Kelly RG, Christiaen L, Levine M, Ziermann JM, Molnar JL, Noden DM, Tzahor E. A new heart for a new head in vertebrate cardiopharyngeal evolution. Nature. 2015;520:466-73.

218. Tzahor E. Heart and craniofacial muscle development: a new developmental theme of distinct myogenic fields. Dev Biol. 2009;327:273-9.

219. Sambasivan R, Gayraud-Morel B, Dumas G, Cimper C, Paisant S, Kelly RG, Tajbakhsh S. Distinct regulatory cascades govern extraocular and pharyngeal arch muscle progenitor cell fates. Dev Cell. 2009;16:810-21.

220. Lescroart F, Hamou W, Francou A, Theveniau-Ruissy M, Kelly RG, Buckingham M. Clonal analysis reveals a common origin between nonsomite-derived neck muscles and heart myocardium. Proc Natl Acad Sci. 2015;112:1446-51.

221. Bothe I, Ahmed MU, Winterbottom FL, von Scheven G, Dietrich S. Extrinsic versus intrinsic cues in avian paraxial mesoderm patterning and differentiation. Dev Dyn. 2007;236:2397-409.

222. Chevallier A, Kieny M, Mauger A. Limb-somite relationship: origin of the limb musculature. J Embryol Exp Morphol. 1977;41:245-58.

223. Christ $B$, Jacob HJ, Jacob M. Experimental analysis of the origin of the wing musculature in avian embryos. Anat Embryol. 1977;150:171-86.

224. Hayashi K, Ozawa E. Vital labelling of somite-derived myogenic cells in the chicken limb bud. Roux's Arch Dev Biology. 1991;200:188-92.

225. Kardon G. Muscle and tendon morphogenesis in the avian hind limb. Development. 1998;125:4019-32.

226. Sambasivan R, Kuratani S, Tajbakhsh S. An eye on the head: the development and evolution of craniofacial muscles. Development. 2011;138:2401-15.

227. Trainor PA, Tam PP. Cranial paraxial mesoderm and neural crest cells of the mouse embryo: co-distribution in the craniofacial mesenchyme but distinct segregation in branchial arches. Development. 1995;121:2569-82.

228. Trainor PA, Tan SS, Tam PP. Cranial paraxial mesoderm: regionalisation of cell fate and impact on craniofacial development in mouse embryos. Development. 1994;120:2397-408

229. Rinon A, Lazar S, Marshall H, Buchmann-Moller S, Neufeld A, ElhananyTamir H, Taketo MM, Sommer L, Krumlauf R, Tzahor E. Cranial neural crest cells regulate head muscle patterning and differentiation during vertebrate embryogenesis. Development. 2007;134:3065-75.

230. Grenier J, Teillet MA, Grifone R, Kelly RG, Duprez D. Relationship between neural crest cells and cranial mesoderm during head muscle development. PLoS ONE. 2009;4:e4381.

231. Kardon G, Harfe BD, Tabin CJ. A Tcf4-positive mesodermal population provides a prepattern for vertebrate limb muscle patterning. Dev Cell. 2003:5:937-44

232. Mathew SJ, Hansen JM, Merrell AJ, Murphy MM, Lawson JA, Hutcheson DA, Hansen MS, Angus-Hill M, Kardon G. Connective tissue fibroblasts and Tcf4 regulate myogenesis. Development. 2011;138:371-84.

233. Solem RC, Eames BF, Tokita M, Schneider RA. Mesenchymal and mechanical mechanisms of secondary cartilage induction. Dev Biol. 2011;356:28-39.

234. Depew MJ, Compagnucci C. Tweaking the hinge and caps: testing a model of the organization of jaws. J Exp Zool B Mol Dev Evol. 2008:310:315-35.

235. Fish JL, Villmoare B, Koebernick K, Compagnucci C, Britanova O, Tarabykin V, Depew MJ. Satb2, modularity, and the evolvability of the vertebrate jaw. Evol Dev. 2011;13:549-64.

236. Mallarino R, Grant PR, Grant BR, Herrel A, Kuo WP, Abzhanov A. Two developmental modules establish 3D beak-shape variation in Darwin's finches. Proc Natl Acad Sci. 2011;108:4057-62.

237. Abzhanov A, Tabin CJ. Shh and Fgf8 act synergistically to drive cartilage outgrowth during cranial development. Dev Biol. 2004:273:134-48.

238. Schoenebeck JJ, Ostrander EA. The genetics of canine skull shape variation. Genetics. 2013;193:317-25.

239. Schoenebeck JJ, Hutchinson SA, Byers A, Beale HC, Carrington B, Faden DL, Rimbault M, Decker B, Kidd JM, Sood R, Boyko AR, Fondon JW 3rd,
Wayne RK, Bustamante CD, Ciruna B, Ostrander EA. Variation of BMP3 contributes to dog breed skull diversity. PLoS Genet. 2012;8:e1002849.

240. Garcez RC, Le Douarin NM, Creuzet SE. Combinatorial activity of Six12-4 genes in cephalic neural crest cells controls craniofacial and brain development. Cell Mol Life Sci. 2014;71:2149-64.

241. Kuraku S, Takio Y, Sugahara F, Takechi M, Kuratani S. Evolution of oropharyngeal patterning mechanisms involving Dlx and endothelins in vertebrates. Dev Biol. 2010;341:315-23.

242. Trainor PA, Ariza-McNaughton L, Krumlauf R. Role of the isthmus and FGFs in resolving the paradox of neural crest plasticity and prepatterning. Science. 2002;295:1288-91.

243. Jeong J, Li X, McEvilly RJ, Rosenfeld MG, Lufkin T, Rubenstein JL. DlX genes pattern mammalian jaw primordium by regulating both lower jaw-specific and upper jaw-specific genetic programs. Development. 2008;135:2905-16.

244. Depew MJ, Simpson CA, Morasso M, Rubenstein JL. Reassessing the Dlx code: the genetic regulation of branchial arch skeletal pattern and development. J Anat. 2005;207:501-61.

245. Richman JM, Lee SH. About face: signals and genes controlling jaw patterning and identity in vertebrates. BioEssays. 2003:25:554-68.

246. Alappat S, Zhang ZY, Chen YP. Msx homeobox gene family and craniofacial development. Cell Res. 2003;13:429-42.

247. Beverdam A, Merlo GR, Paleari L, Mantero S, Genova F, Barbieri O, Janvier $P$, Levi $G$. Jaw transformation with gain of symmetry after DIx5/ Dlx6 inactivation: mirror of the past? Genesis. 2002;34:221-7.

248. Depew MJ, Liu JK, Long JE, Presley R, Meneses JJ, Pedersen RA, Rubenstein JL. DIx5 regulates regional development of the branchial arches and sensory capsules. Development. 1999;126:3831-46.

249. Depew MJ, Lufkin T, Rubenstein JL. Specification of jaw subdivisions by Dlx genes. Science. 2002;298:381-5.

250. Qiu M, Bulfone A, Martinez S, Meneses JJ, Shimamura K, Pedersen RA, Rubenstein JL. Null mutation of D/x-2 results in abnormal morphogenesis of proximal first and second branchial arch derivatives and abnormal differentiation in the forebrain. Genes Dev. 1995;9:2523-38.

251. Qiu M, Bulfone A, Ghattas I, Meneses JJ, Christensen L, Sharpe PT, Presley R, Pedersen RA, Rubenstein JL. Role of the Dlx homeobox genes in proximodistal patterning of the branchial arches: mutations of D|x-1, D|x-2, and D|x-1 and -2 alter morphogenesis of proximal skeletal and soft tissue structures derived from the first and second arches. Dev Biol. 1997;185:165-84.

252. Sato T, Kurihara Y, Asai R, Kawamura Y, Tonami K, Uchijima Y, Heude E, Ekker M, Levi G, Kurihara H. An endothelin-1 switch specifies maxillomandibular identity. Proc Natl Acad Sci. 2008;105:18806-11.

253. Shigetani Y, Nobusada Y, Kuratani S. Ectodermally derived FGF8 defines the maxillomandibular region in the early chick embryo: epithelial-mesenchymal interactions in the specification of the craniofacial ectomesenchyme. Dev Biol. 2000;228:73-85.

254. Shigetani Y, Sugahara F, Kawakami Y, Murakami Y, Hirano S, Kuratani S. Heterotopic shift of epithelial-mesenchymal interactions in vertebrate jaw evolution. Science. 2002;296:1316-9.

255. Thomas T, Kurihara H, Yamagishi H, Kurihara Y, Yazaki Y, Olson EN, Srivastava D. A signaling cascade involving endothelin-1, dHAND and msx 1 regulates development of neural-crest-derived branchial arch mesenchyme. Development. 1998;125:3005-14.

256. Clouthier DE, Williams SC, Yanagisawa H, Wieduwilt M, Richardson JA, Yanagisawa M. Signaling pathways crucial for craniofacial development revealed by endothelin-A receptor-deficient mice. Dev Biol. 2000;217:10-24.

257. Miller CT, Yelon D, Stainier DY, Kimmel CB. Two endothelin 1 effectors, hand 2 and bapx1, pattern ventral pharyngeal cartilage and the jaw joint. Development. 2003;130:1353-65.

258. Ruest LB, Xiang X, Lim KC, Levi G, Clouthier DE. Endothelin-A receptor-dependent and -independent signaling pathways in establishing mandibular identity. Development. 2004:131:4413-23.

259. Tavares AL, Garcia EL, Kuhn K, Woods CM, Williams T, Clouthier DE. Ectodermal-derived Endothelin1 is required for patterning the distal and intermediate domains of the mouse mandibular arch. Dev Biol. 2012;371:47-56.

260. Tavares ALP, Cox TC, Maxson RM, Ford HL, Clouthier DE. Negative regulation of endothelin signaling by SIX 1 is required for proper maxillary development. Development. 2017;144:2021-31. 
261. Trainor PA, Krumlauf R. Patterning the cranial neural crest: hindbrain segmentation and Hox gene plasticity. Nat Rev Neurosci. 2000:1:116-24.

262. Trainor PA, Krumlauf R. Hox genes, neural crest cells and branchial arch patterning. Current Opinions in Cell Biology. 2001;13:698-705.

263. Wilkinson DG, Bhatt S, Cook M, Boncinelli E, Krumlauf R. Segmental expression of Hox-2 homoeobox-containing genes in the developing mouse hindbrain. Nature. 1989;341:405-9.

264. Hunt P, Gulisano M, Cook M, Sham MH, Faiella A, Wilkinson D, Boncinelli E, Krumlauf R. A distinct Hox code for the branchial region of the vertebrate head. Nature. 1991;353:861-4.

265. Schneider RA, Hu D, Rubenstein JL, Maden M, Helms JA. Local retinoid signaling coordinates forebrain and facial morphogenesis by maintaining FGF8 and SHH. Development. 2001;128:2755-67.

266. Lee SH, Fu KK, Hui JN, Richman JM. Noggin and retinoic acid transform the identity of avian facial prominences. Nature. 2001:414:909-12.

267. Parsons TE, Schmidt EJ, Boughner JC, Jamniczky HA, Marcucio RS, Hallgrimsson B. Epigenetic integration of the developing brain and face. Dev Dyn. 2011;240:2233-44

268. Hu D, Marcucio RS. A SHH-responsive signaling center in the forebrain regulates craniofacial morphogenesis via the facial ectoderm. Development. 2009;136:107-16

269. Song Y, Hui JN, Fu KK, Richman JM. Control of retinoic acid synthesis and FGF expression in the nasal pit is required to pattern the craniofacial skeleton. Dev Biol. 2004;276:313-29.

270. Moore-Scott BA, Manley NR. Differential expression of Sonic hedgehog along the anterior-posterior axis regulates patterning of pharyngeal pouch endoderm and pharyngeal endoderm-derived organs. Dev Biol. 2005:278:323-35.

271. Couly G, Creuzet S, Bennaceur S, Vincent C, Le Douarin NM. Interactions between Hox-negative cephalic neural crest cells and the foregut endoderm in patterning the facial skeleton in the vertebrate head. Development. 2002;129:1061-73.

272. Brito JM, Teillet MA, Le Douarin NM. An early role for sonic hedgehog from foregut endoderm in jaw development: ensuring neural crest cell survival. Proc Natl Acad Sci. 2006:103:11607-12.

273. Haworth KE, Wilson JM, Grevellec A, Cobourne MT, Healy C, Helms JA, Sharpe PT, Tucker AS. Sonic hedgehog in the pharyngeal endoderm controls arch pattern via regulation of Fgf8 in head ectoderm. Dev Biology. 2007;303:244-58

274. Adams AE. Some effects of removal of endoderm from the mouth region of early Amblystoma punctatum embryos. J Exp Zool. 1931;58:147-63.

275. Ruhin B, Creuzet S, Vincent C, Benouaiche L, Le Douarin NM, Couly G. Patterning of the hyoid cartilage depends upon signals arising from the ventral foregut endoderm. Dev Dyn. 2003;228:239-46.

276. Graham A, Okabe M, Quinlan R. The role of the endoderm in the development and evolution of the pharyngeal arches. J Anat. 2005:207:479-87.

277. Ahlgren SC, Bronner-Fraser M. Inhibition of sonic hedgehog signaling in vivo results in craniofacial neural crest cell death. Curr Biol. 1999;9:1304-14

278. Ahlgren SC, Thakur V, Bronner-Fraser M. Sonic hedgehog rescues cranial neural crest from cell death induced by ethanol exposure. Proc Natl Acad Sci. 2002;99:10476-81.

279. Sheehan-Rooney K, Swartz ME, Lovely CB, Dixon MJ, Eberhart JK. BMP and $\mathrm{SHH}$ signaling mediate the expression of satb2 in the pharyngeal arches. PLOS ONE. 2013;8:e59533.

280. Harrison RG. Heteroplastic Grafting in Embryology. Baltimore: Williams and Wilkins; 1935

281. Andres G. Untersuchungen an Chimären von Triton und Bombinator. Genetica. 1949;24:387-534.

282. Wagner G. Untersuchungen an Bombinator-Triton-Chimaeren. Roux' Archiv für Entwicklungsmechanik der Organismen. 1959:151:136-58.

283. Schneider RA, Helms JA. The cellular and molecular origins of beak morphology. Science. 2003:299:565-8.

284. Tucker AS, Lumsden A. Neural crest cells provide species-specific patterning information in the developing branchial skeleton. Evol Dev. 2004;6:32-40
285. Mitsiadis TA, Caton J, Cobourne M. Waking-up the sleeping beauty: recovery of the ancestral bird odontogenic program. J Exp Zool Part B. 2006:306:227-33.

286. Mitsiadis TA, Cheraud Y, Sharpe P, Fontaine-Perus J. Development of teeth in chick embryos after mouse neural crest transplantations. Proc Natl Acad Sci. 2003;100:6541-5.

287. Eames BF, Schneider RA. The genesis of cartilage size and shape during development and evolution. Development. 2008;135:3947-58.

288. Merrill AE, Eames BF, Weston SJ, Heath T, Schneider RA. Mesenchymedependent BMP signaling directs the timing of mandibular osteogenesis. Development. 2008;135:1223-34.

289. Trainor PA, Melton KR, Manzanares M. Origins and plasticity of neural crest cells and their roles in jaw and craniofacial evolution. Int J Dev Biol. 2003:47:541-53.

290. Schneider RA. How to tweak a beak: molecular techniques for studying the evolution of size and shape in Darwin's finches and other birds. BioEssays. 2007;29:1-6.

291. Campas O, Mallarino R, Herrel A, Abzhanov A, Brenner MP. Scaling and shear transformations capture beak shape variation in Darwin's finches. Proc Natl Acad Sci. 2010;107:3356-60.

292. Abzhanov A, Kuo WP, Hartmann C, Grant BR, Grant PR, Tabin CJ. The calmodulin pathway and evolution of elongated beak morphology in Darwin's finches. Nature. 2006;442:563-7.

293. Abzhanov A, Protas M, Grant BR, Grant PR, Tabin CJ. Bmp4 and morphological variation of beaks in Darwin's finches. Science. 2004;305:1462-5.

294. Wu P, Jiang TX, Suksaweang S, Widelitz RB, Chuong CM. Molecular shaping of the beak. Science. 2004;305:1465-6.

295. Wu P, Jiang TX, Shen JY, Widelitz RB, Chuong CM. Morphoregulation of avian beaks: comparative mapping of growth zone activities and morphological evolution. Dev Biol. 2006;235:1400-12.

296. Lamichhaney S, Berglund J, Almen MS, Maqbool K, Grabherr M Martinez-Barrio A, Promerova M, Rubin CJ, Wang C, Zamani N, Grant BR, Grant PR, Webster MT, Andersson L. Evolution of Darwin's finches and their beaks revealed by genome sequencing. Nature. 2015;518:371-5.

297. Attanasio C, Nord AS, Zhu Y, Blow MJ, Li Z, Liberton DK, Morrison H, Plajzer-Frick I, Holt A, Hosseini R, Phouanenavong S, Akiyama JA, Shoukry M, Afzal V, Rubin EM, FitzPatrick DR, Ren B, Hallgrimsson B, Pennacchio LA, Visel A. Fine tuning of craniofacial morphology by distant-acting enhancers. Science. 2013;342:1241006

298. Prescott SL, Srinivasan R, Marchetto MC, Grishina I, Narvaiza I, Selleri L, Gage FH, Swigut T, Wysocka J. Enhancer divergence and cis-regulatory evolution in the human and chimp neural crest. Cell. 2015;163:68-83.

299. Tyler MS, Hall BK. Epithelial influences on skeletogenesis in mandible of embryonic chick. Anat Rec. 1977;188:229-39.

300. Hall BK. The induction of neural crest-derived cartilage and bone by embryonic epithelia: an analysis of the mode of action of an epithelialmesenchymal interaction. J Embryol Exp Biol. 1981;64:305-20.

301. Giori NJ, Beaupre GS, Carter DR. Cellular-shape and pressure may mediate mechanical control of tissue composition in tendons. J Orthop Res. 1993;11:581-91

302. Maeda T, Sakabe T, Sunaga A, Sakai K, Rivera AL, Keene DR, Sasaki T, Stavnezer E, lannotti J, Schweitzer R, Ilic D, Baskaran H, Sakai T. Conversion of mechanical force into TGF $\beta$-mediated biochemical signals. Curr Biol. 2011;21:933-41.

303. Blitz E, Viukov S, Sharir A, Shwartz Y, Galloway JL, Pryce BA, Johnson RL, Tabin CJ, Schweitzer R, Zelzer E. Bone ridge patterning during musculoskeletal assembly Is mediated through SCX regulation of Bmp4 at the tendon-skeleton junction. Dev Cell. 2009;17:861-73.

304. Schweitzer R, Zelzer E, VolkT. Connecting muscles to tendons: tendons and musculoskeletal development in flies and vertebrates. Development. 2010;137:2807-17.

305. Sharir A, Stern T, Rot C, Shahar R, Zelzer E. Muscle force regulates bone shaping for optimal load-bearing capacity during embryogenesis. Development. 2011:138:3247-59.

306. Blitz E, Sharir A, Akiyama H, Zelzer E. Tendon-bone attachment unit is formed modularly by a distinct pool of Scx- and Sox9-positive progenitors. Development. 2013;140:2680-90.

307. Sugimoto Y, Takimoto A, Akiyama H, Kist R, Scherer G, Nakamura T, Hiraki Y, Shukunami C. Scx (+)/Sox $9(+)$ progenitors contribute to the establishment of the junction between cartilage and tendon/ligament. Development. 2013;140:2280-8. 
308. Berthet E, Chen C, Butcher K, Schneider RA, Alliston T, Amirtharajah M. Smad3 binds Scleraxis and Mohawk and regulates tendon matrix organization. J Orthop Res. 2013;31:1475-83.

309. Thomopoulos S, Genin GM, Galatz LM. The development and morphogenesis of the tendon-to-bone insertion-what development can teach us about healing. J Musculoskelet Neuronal Interact. 2010;10:35-45.

310. Li KW, Lindsey DP, Wagner DR, Giori NJ, Schurman DJ, Goodman SB, Smith RL, Carter DR, Beaupre GS. Gene regulation ex vivo within a wrap-around tendon. Tissue Eng. 2006;12:2611-8.

311. Hashimoto Y, Yoshida G, Toyoda H, Takaoka K. Generation of tendonto-bone interface "enthesis" with use of recombinant BMP-2 in a rabbit model. J Orthop Res. 2007:25:1415-24.

312. Hall BK. The formation of adventitious cartilage by membrane bones under the influence of mechanical stimulation applied in vitro. Life Sci. 1967:6:663-7.

313. Hall BK. In vitro studies on mechanical evocation of adventitious cartilage in chick. J Exp Zool. 1968;168:283.

314. Hall BK. Immobilization and cartilage transformation into bone in embryonic chick. Anat Rec. 1972:173:391.

315. Hall BK. The role of movement and tissue Interactions in the development and growth of bone and secondary cartilage in the clavicle of the embryonic chick. J Embryol Exp Morphol. 1986;93:133-52.

316. Hall BK, Herring SW. Paralysis and growth of the musculoskeletal system in the embryonic chick. J Morphol. 1990;206:45-56.

317. Wu KC, Streicher J, Lee ML, Hall BK, Muller GB. Role of motility in embryonic development l: embryo movements and amnion contractions in the chick and the influence of illumination. J Exp Zool. 2001:291:186-94.

318. Oppenheim RW. Some aspects of embryonic behaviour in duck (Anas platyrhynchos). Anim Behav. 1970;18:335

319. Oppenheim RW. Light responsivity in chick and duck embryos just prior to hatching. Anim Behav. 1968;16:276

320. Hamburger V, Oppenheim R. Prehatching motility and hatching behavior in chick. J Exp Zool. 1967;166:171.

321. Oppenheim RW. Amniotic contraction and embryonic motility in chick embryo. Science. 1966;152:528.

322. Hammond CL, Simbi BH, Stickland NC. In ovo temperature manipulation influences embryonic motility and growth of limb tissues in the chick (Gallus gallus). J Exp Biol. 2007;210:2667-75.

323. Muller GB. Embryonic motility: environmental influences and evolutionary innovation. Evol Dev. 2003;5:56-60.

324. Bradley NS. Transformations in embryonic motility in chick: kinematic correlates of type I and II motility at E9 and E12. J Neurophysiol. 1999:81:1486-94

325. Lwigale PY, Schneider RA. Other chimeras: quail-duck and mouse-chick. Methods Cell Biol. 2008;87:59-74.

326. Fish JL, Schneider RA. Assessing species-specific contributions to craniofacial development using quail-duck chimeras. JV Exp. 2014;87:1-6.

327. Hosseini A, Hogg DA. The effects of paralysis on skeletal development in the chick-embryo. 1. General effects. J Anat. 1991;177:159-68.

328. Persson M. The role of movements in the development of sutural and diarthrodial joints tested by long-term paralysis of chick-embryos. J Anat. 1983;137:591-9.

329. Murray PDF, Drachman DB. Role of movement in development of joints and related structures_-head and neck in chick embryo. J Embryol Exp Morphol. 1969;22:349

330. Kahn J, Shwartz Y, Blitz E, Krief S, Sharir A, Breitel DA, Rattenbach R, Relaix F, Maire P, Rountree RB, Kingsley DM, Zelzer E. Muscle contraction is necessary to maintain joint progenitor cell fate. Dev Cell. 2009;16:734-43.

331. Lamb KJ, Lewthwaite JC, Lin JP, Simon D, Kavanagh E, Wheeler-Jones $C P D$, Pitsillides AA. Diverse range of fixed positional deformities and bone growth restraint provoked by flaccid paralysis in embryonic chicks. Int J Exp Pathol. 2003;84:191-9.

332. Pitsillides AA. Early effects of embryonic movement: a shot out of the dark'. J Anat. 2006;208:417-31.

333. Pollard AS, McGonnell IM, Pitsillides AA. Mechanoadaptation of developing limbs: shaking a leg. J Anat. 2014;224:615-23.
334 Shwartz Y Farkas Z, Stern T, Aszodi A, Zelzer E. Muscle contraction controls skeletal morphogenesis through regulation of chondrocyte convergent extension. Dev Biol. 2012;370:154-63.

335. Hall BK. Cellular differentiation in skeletal tissues. Biol Rev Camb Philos Soc. 1970:45:455-84.

336. Beresford WA. Chondroid bone, secondary cartilage, and metaplasia. Baltimore: Urban \& Schwarzenberg; 1981.

337. Murray P. Adventitious (secondary) cartilage in the chick, and the development of certain bones and articulation in the chick skull. Aust J Zool. 1963:11:368-430.

338. Murray P, Smiles M. Factors in the evocation of adventitious (secondary) cartilage in the chick embryo. Aust J Zool. 1965;13:351-82.

339. Stutzmann J, Petrovic A. Nature and evolutive aptitudes of cells of the mitotic compartment of the secondary cartilages of the mandible and maxilla of the young rat. Experience with cytotypic culture and homotransplantation. Bull de l'Assoc des Anat. 1975;59:523-34.

340. Vinkka H. Secondary cartilages in the facial skeleton of the rat. Proc Finnish Dent Soc. 1982:78(Suppl 7):1-137.

341. Bailleul AM, Hall BK, Horner JR. First evidence of dinosaurian secondary cartilage in the post-hatching skull of Hypacrosaurus stebingeri (Dinosauria, Ornithischia). PLoS ONE. 2012;7:e36112.

342. Bailleul AM, Hall BK, Horner JR. Secondary cartilage revealed in a nonavian dinosaur embryo. PLoS ONE. 2013;8:e56937.

343. Hall BK. Selective proliferation and accumulation of chondroprogenitor cells as the mode of action of biomechanical factors during secondary chondrogenesis. Teratology. 1979;20:81-91.

344. Fang J, Hall BK. Chondrogenic cell differentiation from membrane bone periostea. Anat Embryol. 1997;196:349-62.

345. Washburn SL. The relation of the temporal muscle to the form of the skull. Anat Rec. 1947;99:239-48.

346. Horowitz SL, Shapiro HH. Modifications of mandibular architecture following removal of temporalis muscle in the rat. J Dent Res. 1951:30:276-80.

347. Moore WJ. An experimental study of the functional components of growth in the rat mandible. Acta Anat. 1973;85:378-85.

348. Soni NN, Malloy RB. Effect of removal of the temporal muscle on the coronoid process in guinea pigs: quantitative triple fluorochrome study. J Dent Res. 1974:53:474-80.

349. Kantomaa T, Rönning O. Growth mechanisms of the mandible. In: Dixon AD, Hoyte DAN, Rönning O, editors. Fundamentals of craniofacial growth. Boca Raton: CRC Press; 1997. p. 189-204.

350. Anthwal N, Peters H, Tucker AS. Species-specific modifications of mandible shape reveal independent mechanisms for growth and initiation of the coronoid. EvoDevo. 2015;6:35.

351. Boyd TG, Castelli WA, Huelke DF. Removal of the temporalis muscle from its origin: effects on the size and shape of the coronoid process. J Dent Res. 1967:46:997-1001.

352. Moss ML, Meehan MA. Functional cranial analysis of the coronoid process in the rat. Acta Anat. 1970;77:11-24.

353. Shibata S, Suda N, Fukada K, Ohyama K, Yamashita Y, Hammond VE. Mandibular coronoid process in parathyroid hormone-related proteindeficient mice shows ectopic cartilage formation accompanied by abnormal bone modeling. Anat Embryol. 2003:207:35-44.

354. Rot-Nikcevic I, Downing KJ, Hall BK, Kablar B. Development of the mouse mandibles and clavicles in the absence of skeletal myogenesis. Histol Histopathol. 2007;22:51-60.

355. Zweers G. Structure, movement, and myography of the feeding apparatus of the mallard (Anas platyrhynchos L.). A study in functional anatomy. Neth J Zool. 1974;24(4):323-467.

356. Zweers GA, Kunz G, Mos J. Functional anatomy of the feeding apparatus of the mallard (Anas platyrhynchos) structure, movement, electromyography and electro-neurography. Anat Anz. 1977:142:10-20.

357. Yuodelis RA. The morphogenesis of the human temporomandibular joint and its associated structures. J Dent Res. 1966:45:182-91.

358. Spyropoulos MN. The morphogenetic relationship of the temporal muscle to the coronoid process in human embryos and fetuses. Am J Anat. 1977;150:395-409.

359. Hems T, Tillmann B. Tendon entheses of the human masticatory muscles. Anat Embryol. 2000;202:201-8. 
360. Dawson MM, Metzger KA, Baier DB, Brainerd EL. Kinematics of the quadrate bone during feeding in mallard ducks. J Exp Biol. 2011;214:2036-46.

361. Zweers GA. Bill tip organ and mechanics of feeding of mallard. Am Zool. 1976;16:215.

362. Zweers GA, Gerritsen AFC, Vankranenburg P. Mechanics of Feeding of Mallard, Anas platyrhynchos_-structure, cineradiography, myography. Anatom Record. 1976;184:571.

363. McLeod WM. Avian Anatomy. Minneapolis: Burgess Pub. Co.; 1964.

364. Van den Heuvel WF. Kinetics of the skull in the chicken (Gallus gallus domesticus). Neth J Zool. 1992;42:561-82.

365. Baumel JJ. Handbook of avian anatomy: nomina anatomica avium. Cambridge: Nuttall Ornithological Club; 1993.

366. Fitzgerald TC. The coturnix quail: anatomy and histology. Ames: lowa State University Press; 1969.

367. Jollie M. The head skeleton of the chicken and remarks on the anatomy of this region in other birds. J Morphol. 1957;100:389-436.

368. Merida-Velasco JR, Rodriquez-Vazquez JF, Merida-Velasco JA, SanchezMontesinos I, Espin-Ferra J, Jimenez-Collado J. Development of the human temporomandibular joint. Anat Rec. 1999;255:20-33.

369. Merida-Velasco JR, Rodriguez-Vazquez JF, De la Cuadra Blanco C, Campos-Lopez R, Sanchez M, Merida-Velasco JA. Development of the mandibular condylar cartilage in human specimens of 10-15 weeks' gestation. J Anat. 2009;214:56-64.

370. LeResche L. Epidemiology of temporomandibular disorders: implications for the investigation of etiologic factors. Crit Rev Oral Biol Med. 1997:8:291-305.

371. Liu F, Steinkeler A. Epidemiology, diagnosis, and treatment of temporomandibular disorders. Dent Clin North Am. 2013;57:465-79.

372. Wadhwa S, Kapila S. TMJ disorders: future innovations in diagnostics and therapeutics. J Dent Educ. 2008:72:930-47.

373. Robling AG, Niziolek PJ, Baldridge LA, Condon KW, Allen MR, Alam I, Mantila SM, Gluhak-Heinrich J, Bellido TM, Harris SE, Turner CH. Mechanical stimulation of bone in vivo reduces osteocyte expression of Sost/sclerostin. J Biol Chem. 2008;283:5866-75.

374. Tu XL, Rhee Y, Condon KW, Bivi N, Allen MR, Dwyer D, Stolina M, Turner $\mathrm{CH}$, Robling AG, Plotkin LI, Bellido T. Sost downregulation and local Wnt signaling are required for the osteogenic response to mechanical loading. Bone. 2012;50:209-17.

375. Robling AG, Kang KS, Bullock WA, Foster WH, Murugesh D, Loots GG, Genetos DC. Sost, independent of the non-coding enhancer ECR370, is required for bone mechanoadaptation. Bone. 2016:92:180-8.

376. Vincent TL, McLean CJ, Full LE, Peston D, Saklatvala J. FGF-2 is bound to perlecan in the pericellular matrix of articular cartilage, where it acts as a chondrocyte mechanotransducer. Osteoarth Cartil. 2007;15:752-63.

377. Raizman I, De Croos JN, Pilliar R, Kandel RA. Calcium regulates cyclic compression-induced early changes in chondrocytes during in vitro cartilage tissue formation. Cell Calcium. 2010;48:232-42.

378. Mammoto T, Ingber DE. Mechanical control of tissue and organ development. Development. 2010;137:1407-20.

379. Matthews BD, Overby DR, Mannix R, Ingber DE. Cellular adaptation to mechanical stress: role of integrins, Rho, cytoskeletal tension and mechanosensitive ion channels. J Cell Sci. 2006:119:508-18.

380. Ramage L, Nuki G, Salter DM. Signalling cascades in mechanotransduction: cell-matrix interactions and mechanical loading. Scand J Med Sci Sports. 2009;19:457-69.

381. Roberts SR, Knight MM, Lee DA, Bader DL. Mechanical compression influences intracellular $\mathrm{Ca}(2+)$ signaling in chondrocytes seeded in agarose constructs. J Appl Physiol. 2001;90:1385-91.

382. Wang N, Tytell JD, Ingber DE. Mechanotransduction at a distance: mechanically coupling the extracellular matrix with the nucleus. Nat Rev Mol Cell Biol. 2009;10:75-82.
383. Hamill OP, McBride DW. The pharmacology of mechanogated membrane ion channels. Pharmacol Rev. 1996;48:231-52.

384. McBeath R, Pirone DM, Nelson CM, Bhadriraju K, Chen CS. Cell shape, cytoskeletal tension, and RhoA regulate stem cell lineage commitment. Dev Cell. 2004;6:483-95.

385. Dupont S, Morsut L, Aragona M, Enzo E, Giulitti S, Cordenonsi M, Zanconato F, Le Digabel J, Forcato M, Bicciato S, Elvassore N, Piccolo S. Role of YAP/TAZ in mechanotransduction. Nature. 2011;474:179-212.

386. del Rio A, Perez-Jimenez R, Liu RC, Roca-Cusachs P, Fernandez JM, Sheetz MP. Stretching single talin rod molecules activates vinculin binding. Science. 2009;323:638-41.

387. Pruitt BL, Dunn AR, Weis WI, Nelson WJ. Mechano-transduction: from molecules to tissues. PLoS Biol. 2014;12:e1001996.

388. Murakami S, Kan M, McKeehan WL, de Crombrugghe B. Up-regulation of the chondrogenic Sox9 gene by fibroblast growth factors is mediated by the mitogen-activated protein kinase pathway. Proc Natl Acad Sci. 2000;97:1113-8.

389. Govindarajan V, Overbeek PA. FGF9 can induce endochondral ossification in cranial mesenchyme. BMC Dev Biol. 2006;6:7.

390. Robbins JR, Evanko SP, Vogel KG. Mechanical loading and TGF $\beta$ regulate proteoglycan synthesis in tendon. Arch Biochem Biophys. 1997;342:203-11.

391. Derynck R, Piek E, Schneider RA, Choy L, Alliston T. TGF $\beta$ family signalling in mesenchymal differentiation. In: Derynck R, Miyazono K, editors. The TGF-beta family. Cold Spring Harbor: Cold Spring Harbor Laboratory Press; 2008. p. 613-66.

392. Chang JL, Brauer DS, Johnson J, Chen CG, Akil O, Balooch G, Humphrey MB, Chin EN, Porter AE, Butcher K, Ritchie RO, Schneider RA, Lalwani A, Derynck R, Marshall GW, Marshall SJ, Lustig L, Alliston T. Tissue-specific calibration of extracellular matrix material properties by transforming growth factor-beta and Runx 2 in bone is required for hearing. EMBO Rep. 2010;11:765-71.

393. Balooch G, Balooch M, Nalla RK, Schilling S, Filvaroff EH, Marshall GW, Marshall SJ, Ritchie RO, Derynck R, Alliston T. TGF $\beta$ regulates the mechanical properties and composition of bone matrix. Proc Natl Acad Sci. 2005;102:18813-8.

394. Lorda-Diez Cl, Montero JA, Martinez-Cue C, Garcia-Porrero JA, Hurle $J \mathrm{M}$. Transforming growth factors beta coordinate cartilage and tendon differentiation in the developing limb mesenchyme. J Biol Chem. 2009:284:29988-96.

395. Verma PS. Chordate zoology. Chennai: S. Chand Limited; 2013.

396. Shaffer HB, Minx P, Warren DE, Shedlock AM, Thomson RC, Valenzuela N, Abramyan J, Amemiya CT, Badenhorst D, Biggar KK, Borchert GM, Botka CW, Bowden RM, Braun EL, Bronikowski AM, Bruneau BG, Buck LT, Capel B, Castoe TA, Czerwinski M, Delehaunty KD, Edwards SV, Fronick CC, Fujita MK, Fulton L, Graves TA, Green RE, Haerty W, Hariharan R, Hernandez O, Hillier LW, Holloway AK, Janes D, Janzen FJ, Kandoth C, Kong L, de Koning AP, Li Y, Literman R, McGaugh SE, Mork L, O'Laughlin M, Paitz RT, Pollock DD, Ponting CP, Radhakrishnan S, Raney BJ, Richman JM, St John J, Schwartz T, Sethuraman A, Spinks PQ, Storey KB, Thane N, Vinar T, Zimmerman LM, Warren WC, Mardis ER, Wilson RK. The western painted turtle genome, a model for the evolution of extreme physiological adaptations in a slowly evolving lineage. Genome Biol. 2013;14:R28.

\section{Publisher's Note}

Springer Nature remains neutral with regard to jurisdictional claims in published maps and institutional affiliations. 